\title{
Wnt Signaling in the Regulation of Immune Cell and Cancer Therapeutics
}

\author{
Muhammad Haseeb ${ }^{D}$, Rameez Hassan Pirzada, Qurat Ul Ain and Sangdun Choi * (두 \\ Department of Molecular Science and Technology, Ajou University, Suwon 16499, Korea; \\ haseeb3389@hotmail.com (M.H.); rameez_hassan99@yahoo.com (R.H.P.); ainne.w@gmail.com (Q.U.A.) \\ * Correspondence: sangdunchoi@ajou.ac.kr
}

Received: 8 September 2019; Accepted: 1 November 2019; Published: 3 November 2019

\begin{abstract}
Wnt signaling is one of the important pathways to play a major role in various biological processes, such as embryonic stem-cell development, tissue regeneration, cell differentiation, and immune cell regulation. Recent studies suggest that Wnt signaling performs an essential function in immune cell modulation and counteracts various disorders. Nonetheless, the emerging role and mechanism of action of this signaling cascade in immune cell regulation, as well as its involvement in various cancers, remain debatable. The Wnt signaling in immune cells is very diverse, e.g., the tolerogenic role of dendritic cells, the development of natural killer cells, thymopoiesis of T cells, B-cell-driven initiation of T-cells, and macrophage actions in tissue repair, regeneration, and fibrosis. The purpose of this review is to highlight the current therapeutic targets in (and the prospects of) Wnt signaling, as well as the potential suitability of available modulators for the development of cancer immunotherapies. Although there are several Wnt inhibitors relevant to cancer, it would be worthwhile to extend this approach to immune cells.
\end{abstract}

Keywords: Wnt signaling; immune cell regulation; cancer; therapeutic target; inhibitor

\section{Introduction}

Wnt signaling performs a wide variety of essential tasks in the human body by regulating cell differentiation, proliferation, embryonic growth, stem cell development, immune cell functions, and tissue repair and regeneration [1,2]. Various communication mechanisms such as chemical signals exist between the Wnt protein and a receptor called Frizzled (FZD), to execute these tasks in a coordinated manner. In mammals, there are 19 distinct Wnt-type ligands (hereafter "Wnt ligands"), which bind to various receptors including 10 FZD proteins, and numerous co-receptors such as lipoprotein receptor-related proteins (LRP5 and LRP6). The Nusse laboratory at Stanford University has done tremendous work and gathered a large amount of information on Wnt signaling (see "The Wnt homepage" www.stanford.edu/group/nusselab/cgi-bin/wnt/). Wnt signaling is classified into canonical and noncanonical pathways: (1) the canonical one involves cadherin-associated protein $\beta$ ( $\beta$-catenin), T-cell factor (TCF), and lymphocyte enhancer-binding factor (LEF); and (2) the noncanonical pathway, includes the planar cell polarity (PCP) pathway and Wnt calcium pathway (Wnt-Ca ${ }^{2+}$ ) [3]. Dysregulation of the Wnt signaling cascade and aberrant expression of Wnt ligands causes several disorders such as autoimmune diseases, osteoarthritis, asthma, allergy, and cancer [2,4]. Recently, immunologists reported in a number of studies that Wnt signaling and Wnt ligands play an essential and considerable role in the regulation of immune cells. Therefore, a detailed study is needed to understand the mechanisms of the Wnt signaling pathway and the impact of Wnt ligands on immune cell modulation and various diseases. Here, we review the mechanisms of Wnt signaling and the effects of Wnt ligands on immune cell modulation. First, we briefly explain the activation mechanisms of the canonical and noncanonical Wnt signaling pathways. Then, we discuss the involvement of Wnt 
signaling and recent findings of Wnt ligands and related proteins in the regulation of such immune cells as dendritic cells (DCs), natural killer (NK) cells, T cells, macrophages, and B cells. Next, we address the participation of Wnt signaling and the respective ligands in breast cancer, leukemia, gastrointestinal cancers (GCs), and brain cancers. Lastly, we highlight the current therapeutic targets in Wnt signaling and the possible suitability of the available modulators for the development of cancer immunotherapies.

\section{Molecular Players in Canonical and Noncanonical Wnt Pathways}

\subsection{Wnt- $\beta$-Catenin Signaling}

In Wnt- $\beta$-catenin signaling, activation of the cascade is triggered by the binding of a Wnt ligand (Wnt1, Wnt2, Wnt3, Wnt3a, Wnt7a, Wnt7b, Wnt8a, Wnt8b, Wnt10b, or Wnt16) to its respective FZD family receptor (ten such receptors in humans and mice) and low-density co-receptor LRP5 or LRP-6 (Figure 1) [5-7]. The activation of the Wnt receptor complex triggers downstream signaling, which causes the accumulation of $\beta$-catenin in the cytoplasm and its eventual translocation into the nucleus, where it can interact with transcription factors TCF and LEF and activate Wnt target genes cyclin D1 (CCND1), AXIN2, the Myc proto-oncogene, and dickkopf 1 (DKK1) [8]. When Wnt signaling is inactive, $\beta$-catenin levels are kept low by a destruction complex. This complex is composed of protein kinases, including casein kinase 1 (CK1), glycogen synthase kinase $3 \beta$ (GSK3 $\beta$ ), adenomatous polyposis coli (APC), and axin. The activation of the Wnt- $\beta$-catenin signaling pathway is involved in many cellular functions: cell cycle regulation, cell proliferation, apoptosis, stem cell development, differentiation of progenitor cells, and immune cell regulation [1,2]. Recently, it was reported that canonical Wnt-TCF signaling can regulate immune cell-mediated responses of T cells and DCs and stabilizes immunity [9]. Consequently, the aberrant activation of this cascade causes various immune disorders and cancers.

\subsection{Noncanonical Wnt Signaling}

In the noncanonical Wnt pathway, signaling is activated upon binding of a Wnt5a class ligand (Wnt4, Wnt5a, Wnt5b, Wnt6, or Wnt11). The noncanonical Wnt signaling pathway is classified into 2 pathways: the PCP pathway and Wnt- $\mathrm{Ca}^{2+}$ pathway (Figure 1). The PCP pathway takes part in the regulation of cellular polarization, adhesion, stem cell maintenance, embryonic development, and cell invasion and migration [10]. Molecular factors of the Wnt signaling pathway, typically Wnt4, Wnt5a, Wnt5b, and Wnt11, bind to receptors of the FZD family, receptor-like tyrosine kinase (RYK), receptor tyrosine kinase-like orphan receptor 1 or 2 (ROR1 or ROR2), and protein tyrosine kinase 7 (PTK7), which trigger the noncanonical PCP pathway. There are several other important components of the Wnt-PCP pathway including Dvl1-3, prickle-like proteins 1-4 (PRICKLE1-4), Vang-like proteins 1 and 2 (VANGL1/2), cadherin EGF LAG seven-pass G-type receptors 1-3 (CELSR1-3), and small G proteins Rho and Ras-related C3 botulinum toxin substrate 1 (Rac1) [11]. In the PCP pathway, signals are transformed to actin cytoskeletal movements through Rho and Rac, and then, Rho-associated kinase activates Jun N-terminal kinase (JNK)-dependent transcription. Recently, it was reported that receptor RYK might regulate the development of NK cells, and the role of RYK in hematopoiesis was proposed [12]. Moreover, noncanonical Wnt signaling via receptor tyrosine kinases (RTKs), such as ROR1, ROR2, and RYK, activates phosphatidylinositol-3 kinase-AKT (PI3K-AKT) signaling and is involved in numerous cancers including breast cancer, GCs, leukemia, and brain cancer $[13,14]$. 


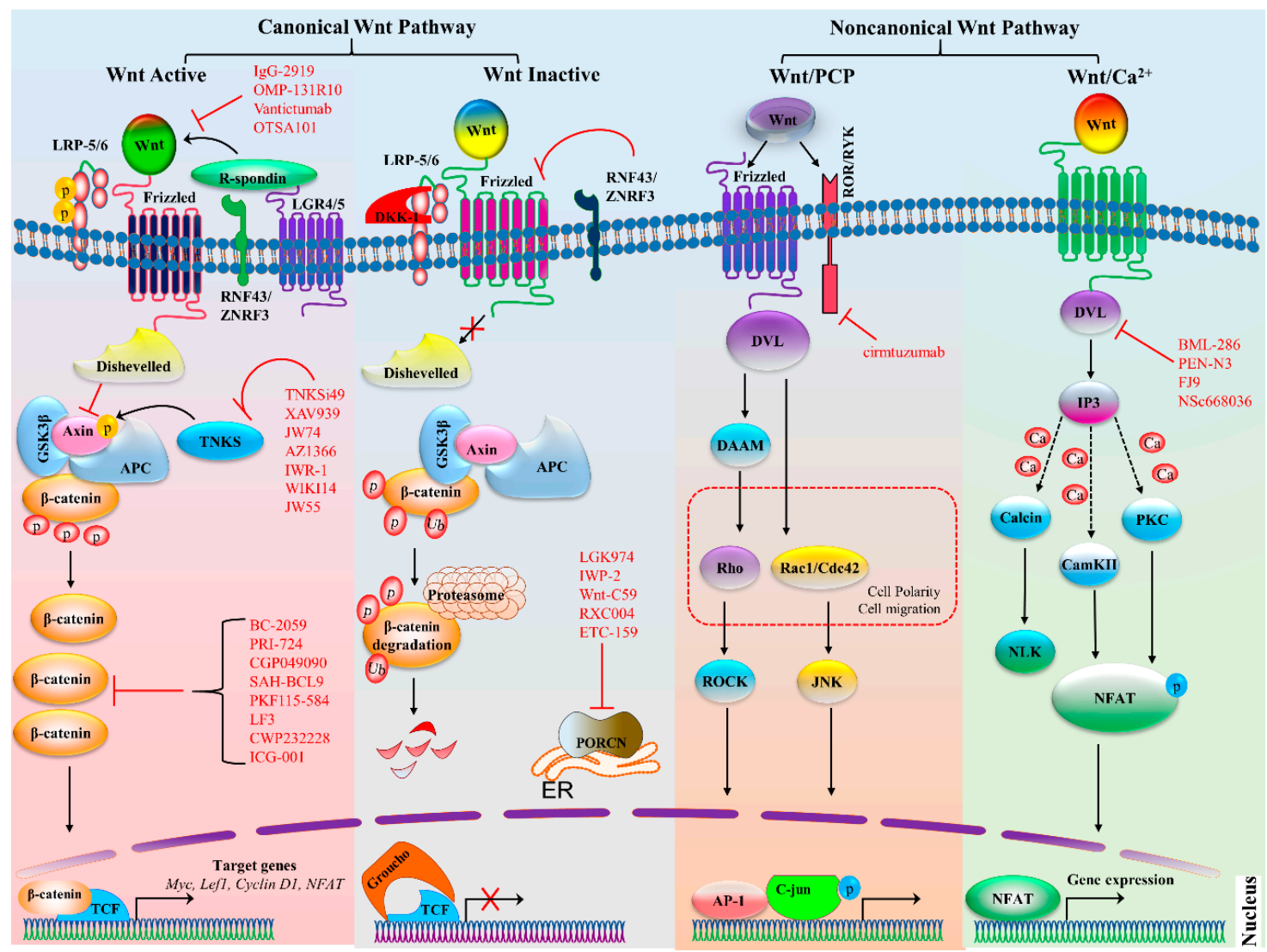

Figure 1. Canonical and noncanonical Wnt signaling pathways. The canonical Wnt pathway is activated by the binding of a Wnt ligands to a frizzled (FZD) family receptor and co-receptor LRP5 or LRP6, which recruits disheveled (Dvl), consequently inactivating the destruction complex composed of APC, GSK $3 \beta$, and axin. This inactivation prevents $\beta$-catenin from proteasomal degradation and allows for the accumulation of $\beta$-catenin, which then enters the nucleus. There, it binds to transcription factor TCF or LEF and initiates the transcription of target genes. Tankyrases (TNKSs) also promote signaling by targeting axin for degradation. Moreover, when R-spondin binds to LGR4 or LGR5, RNF43, and ZNRF3, it is not capable of targeting FZD family receptors for degradation and enhances Wnt signaling. There are various inhibitors of the Wnt signaling pathway, particularly those targeting Wnt ligands, Dvl, TNKS, $\beta$-catenin, and PORCN, which are highlighted in red; bars indicate the inhibitory effect. In the absence of Wnt ligands, the destruction complex becomes active and starts the proteasomal degradation of $\beta$-catenin. Proteins RNF43 and ZNRF3 also inhibit the binding of FZD and target it for degradation. The noncanonical Wnt-PCP pathway is triggered by Wnt ligands that increase the heterodimerization of a receptor-like tyrosine kinase (RYK) and tyrosine kinase-like orphan receptor (ROR). The binding to the receptor activates the Dvl protein and downstream signaling, for instance, DAAM activates GTPases Rho and ROCK, whereas the activation of c-Jun N-terminal kinase (JNK) by Rac is independent of DAAM. They collectively regulate cell polarity and migration and have also been implicated in cancer. The Wnt- $\mathrm{Ca}^{2+}$ pathway is activated by ligand Wnt, which raises the intracellular $\mathrm{Ca}^{2+}$ levels and generates inositol 1,4,5-triphosphate-3 (IP3). The $\mathrm{Ca}^{2+}$ levels increase and switch on downstream $\mathrm{Ca}^{2+}$-dependent enzymes such as calmodulin-dependent protein kinase (CaMKII), calcineurin, and protein kinase C (PKC). As a consequence, CaMKII and PKC phosphorylate nuclear factor of activated T cells (NFAT) and activate the expression of target genes. Protein symbols and abbreviations: APC, adenomatous polyposis coli protein; AP-1, activator protein 1; DKK1, dickkopf related protein 1; ER, endoplasmic reticulum; GSK3 $\beta$, glycogen synthase kinase $3 \beta$; LEF1, lymphoid enhancer-binding factor 1; LRP, lipoprotein receptor-related protein; LGR4/5, Leucine-rich-repeat-containing G protein-coupled receptor 4 or 5; NLK, Nemo like kinase; RNF43, Ring finger protein 43; and ZNRF3, zinc ring finger 3. 
In the noncanonical Wnt-Ca ${ }^{2+}$ pathway, ligand Wnt5a interacts with receptor FZD along with co-receptor ROR1 or ROR2, causing a release of $\mathrm{Ca}^{2+}$ from the endoplasmic reticulum and activating phospholipase C (PLC) through G protein and SEC14-like protein 2 (SEC14L2), resulting in the formation of 1,2-diacylglycerol (DAG) and inositol 1,4,5-triphosphate (IP3) [13,15]. Previously, it has been revealed that Wnt ligands activate several downstream $\mathrm{Ca}^{2+}$-dependent enzymes such as calcineurin, protein kinase C (PKC), and calmodulin-dependent kinase II (CaMKII) [16,17]. Moreover, calcineurin, PKC, and CaMKII participate in various cellular phenomena including cell differentiation, migration, and adhesion through the regulation of transcription factors myocyte enhancer factor 2 (MEF2) and nuclear factor of activated T cells (NFAT) [18].

Noncanonical Wnt ligands substantially participate in the inhibition of canonical signaling; calcineurin and CaMKII stimulation triggers Nemo-like kinase (NLK) and inhibits Wnt- $\beta$-catenin signaling [19]. It has been stated that the $\mathrm{Wnt}-\mathrm{Ca}^{2+}$ signaling pathway is strongly associated with tumorigenesis and cancer progression. Several studies show that ligand Wnt5a often activates the Wnt-Ca ${ }^{2+}$ pathway in cancer cells and higher expression of Wnt5a suppresses breast and colorectal cancer (CRC) $[20,21]$. Collectively, the detailed mechanisms of action of canonical and noncanonical Wnt ligands, and their signaling cascades in immune cells with respect to diseases and treatments, are still debated and require research for the subsequent development of therapeutics.

\section{Wnt Signaling in Immune Cell Regulation}

The development and regulation of immune cells originate from hematopoietic stem cells (HSCs). The latter can retain self-renewal enabling differentiation and regeneration to produce mature blood cells is critical to survival [22]. During development, murine embryonic hematopoiesis takes place at different anatomical sites (extraembryonic yolk sac, placenta, and aorta-gonad-mesonephros (AGS)). These HSCs then move into and seed different organs; normal adult hematopoiesis occurs in bone marrow and follows a series of developmental steps (Figure 2a). Furthermore, the response of HSCs can be divided into two phases: (a) Long-term HSCs (LT-HSCs) possess the capacity for both differentiation and self-renewal for a long time, (b) and short-term HSCs (ST-HSCs) can perform restoration for a limited time. These ST-HSCs give rise to multipotent progenitor cells, myeloid lineage cells (macrophages and granulocytes), and lymphoid progenitor cells (NK cells, dendritic cells, B cells, and T cells), while DCs have partial lineage connections. In this review, we mainly focus on the role of Wnt signaling in lymphoid and myeloid progenitor cells.

In this context, Wnt signaling is a key player and a vital part of immune cell modulation, development, activation, regeneration, and downregulation (Figure 2b). The involvement of Wnt signaling in the immune system was initially reported in relation to T-cell development in the thymus [3]. The Wnt- $\beta$-catenin signaling pathway is widely studied because it helps to direct immune cell infiltration and is looming large as a new putative target for molecular therapeutics of cancer [23]. 

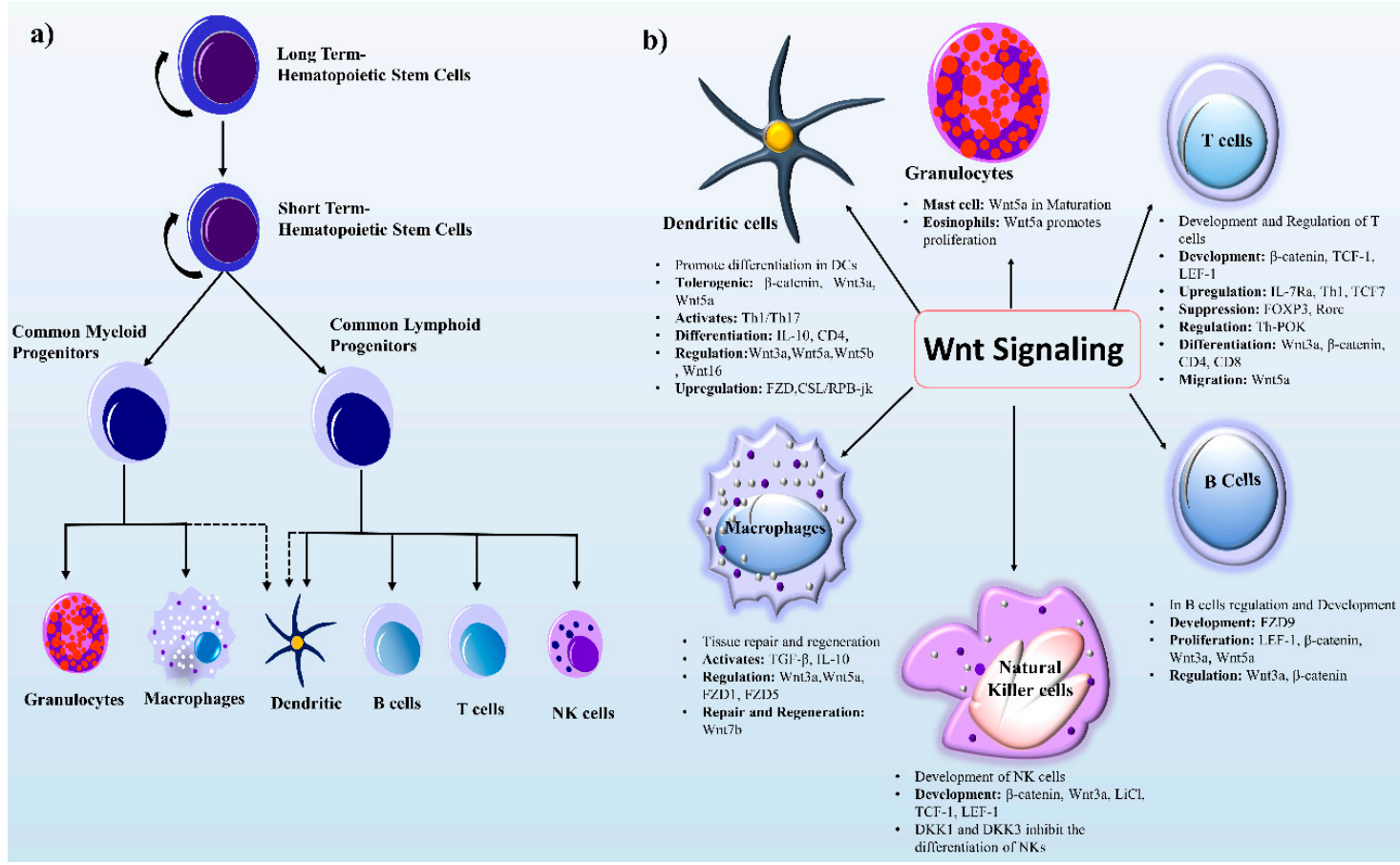

Figure 2. HSC development and Wnt signaling components in immune cell regulation. (a) Differentiated blood cells are generated from self-renewing LT-HSCs, which are capable of differentiation and self-renewal. When LT-HSCs differentiate, they form ST-HSCs with a limited self-renewal capability. The ST-HSCs next produce the multipotent non self-renewing common myeloid linage (granulocytes and macrophages) and common lymphoid lineage (B cells, T cells, and NK cells). The dashed lines show partial progenitor connections. (b) Wnt signaling components play role in myeloid and lymphoid lineage cells. Wnt ligands (Wnt3a, Wnt5a, Wnt5b, and Wnt16) and receptors (FZD1 and FZD5) take part in the regulation of immune cells. The major role of Wnt signaling in B cells, T cells, and NK cells is development. By contrast, in macrophages, this signaling governs tissue repair and regeneration. Wnt signaling and its components perform different tasks in immune cells such as activation, proliferation, migration, tolerogenesis, and up- and down-regulation of genes as shown in text boxes. Protein symbols and abbreviations: CD4, cluster of differentiation 4; DCs, dendritic cells; DKK, dickkopf-related protein; FZD, frizzled; FOXP3, forkhead box P3; IL-10, interleukin 10; IL7Ra, interleukin 7 receptor $\alpha$; LEF1, lymphoid enhancer-binding factor 1; LiC1, ligand-gated ion channel; NKs, natural Killer cells; RORC, related orphan receptor $\mathrm{C}$; TH1, T helper 1 cell; TGF $\beta$, transforming growth factor $\beta$; Th-POK, a zinc finger protein.

\subsection{Wnt Signaling in Lymphoid-Originated Immune Cells}

\subsubsection{Wnt Signaling in DCs}

DCs are antigen-presenting cells of the mammalian immune system that regulate an adaptive immune response. DCs are essential for the maintenance of the balance between tolerance and immunity, and the outcome of an immune response is determined by the type of released cytokines [24]. The ability of DCs to induce both pro- and anti-inflammatory responses is due to the existence of various recently discovered regulatory mechanisms, including the cross-talk between Wnt- $\beta$-catenin and Toll-like receptor (TLR) cascades [25]. A study indicates that both Wnt signaling and Notch signaling promotes differentiation into DCs in humans and mice, both in vivo and in vitro [26]. Notch signaling is an upstream regulator of the Wnt pathway in HSCs via the upregulation of the FZD family of Wnt receptors, which is regulated by the CSL (RBP-JK) transcription factor [26]. Co-receptors LRP5 and LRP6 are critical mediators of the canonical Wnt signaling pathway [2,27]. On the other hand, specific ablation of LRP5 and LRP6 in DCs is associated with delayed tumor progression and enhanced 
host anti-tumor immunity [28]. The Wnt pathway conditions DCs into a regulatory state when they surround a tumor microenvironment (TME) and suppress host immune activity against the tumor [29]. Some members of the Wnt signaling family Wnt $3 a, W n t 5 b$, and Wnt 16 activate the $\beta$-catenin-TCF pathway in DCs [24]. The activation of Wnt3a or deletion of GSK-3 $\beta$ also stimulates the Wnt- $\beta$-catenin pathway and the specific inhibitor SB216763 suppresses GSK-3 $\beta$ activity [30].

A study has been conducted to further discern the effect of the Wnt- $\beta$-catenin signaling pathway on regulatory versus inflammatory responses, where specific ablation of $\beta$-catenin in DCs increased inflammatory responses. Consequently, $\beta$-catenin is associated with a tolerogenic state and helps to control colitis in a murine model [31]. Accordingly, the mechanism behind immunological tolerance driven by DCs attributed to $\beta$-catenin has been elucidated by expression of vitamin A-metabolizing enzymes and interleukin 10 (IL-10) in combination with such signaling molecules as Fas, phosphoinositide-specific phospholipase C (PLC $\gamma 2$ ), mitogen-activated protein kinases (MAPKs), TLRs, and PI3K with AKT [32-35]. An alternate method of $\beta$-catenin-controlled immunological tolerance mediated by DCs is the induction of a specific disruption in the interactions involving homophilic E-cadherin [36]. Although the ablation of homophilic E-cadherin induces maturation of DCs, it inhibits the production of proinflammatory cytokines, thus resulting in the differentiation of progenitors into IL-10-producing cluster of differentiation 4-positive $\left(\mathrm{CD} 4^{+}\right) \mathrm{T}$ cells. In a murine model, Wnt3a and Wnt5a induce activation of a tolerogenic response among DCs by altering their responses to lipopolysaccharide; on the contrary, they do not cause any changes in DC maturation [37]. Moreover, a melanoma-derived Wnt ligand (Wnt5a) facilitates the activation of $\beta$-catenin signaling, which causes an increment in the production of indoleamine 2,3-dioxygenase (IDO) in DCs, leading to the increased production of regulatory $\mathrm{T}$ cells $[38,39]$.

In cancer, immunosuppression is promoted by dysfunctional DCs in the TME [40,41]. Increased levels of Wnts in the TME can trigger paracrine signaling and regulate host antitumor immunity [42,43]. In a TME, DCs metabolize vitamin A to retinoic acid. In addition, high levels of IL-10 and TGF $\beta$ expressed by DCs induce immune tolerance through $\mathrm{CD}^{+}$and $\mathrm{CD} 8^{+} \mathrm{T}$ cells [27]. Of note, IL-10 production is dependent on $\beta$-catenin/TCF4 and mTOR pathways $[28,44]$. Furthermore, a recent study suggests that Wnt 1 induces a tolerogenic response in lung adenocarcinoma. Wnt1 inhibits CC and CXC motif chemokine transcription in DCs via the downregulation of transcription factor Cebpb, which is inversely related to T-cell abundance and thereby induces a tolerogenic response in lung cancer [45]. As discussed above, enhanced Wnt signaling promotes tumor progression and may contribute to immune evasion. Thus, further studies are needed to investigate distinct ways to alter Wnt signaling in tumor cells; this approach may cause beneficial changes in the TME and improve cancer treatment.

\subsubsection{Wnt Signaling in NK cells}

The Wnt- $\beta$-catenin signaling pathway has been implicated in the development of NK cells and activates natural killer T (NKT) cell development and function [46]. Wnt3a primarily signals via the $\beta$-catenin dependent pathway, and a study indicates that exposure to Wnt3a or lithium chloride enhances NK-cell production and changes the differentiation potential of human thymic progenitors [47]. In contrast, the coculturing of human $\mathrm{CD} 34^{+} \mathrm{CD} 38^{-/ \text {low }} \mathrm{HSC}$ s with OP9 stromal cells expressing Wnt3a induces a reduction in the number of NK cells isolated from these HSCs [48]. Nonetheless, active Wnt3a signaling in OP9 stromal cells causes an alteration in the transcriptional profile of these stromal cells, suggesting that the variation in the stromal-cell phenotype could contribute to the reduction in the differentiation into NK cells [48]. The altered outcomes of NK-cell differentiation because of Wnt3a expression highlight the role of other (unidentified) ligands and pathways that are yet to be explored. Human CD34 ${ }^{+}$HSCs when cultured under the conditions favorable for differentiation into NK cells with hydrocortisone, stromal cells, and cytokines (IL-3, IL-7, IL-15, Fms-related tyrosine kinase 3 ligand [FLT3L], and stem cell factors) show increased mRNA expression of LEF1 and TCF1 in contrast to suboptimal differentiation conditions with cytokines only [46,49]. Nonetheless, any blockage of the Wnt signaling pathway negatively influences their differentiation into NK cells. For example, the 
introduction of DKK1, which is a natural inhibitor of $\beta$-catenin dependent Wnt signaling, leads to a reduction in the number of NK cells, which normally develop under these conditions [46]. Another factor, such as DKK1, DKK2, or DKK4, inhibits the Wnt signaling pathway, where DKK3 does not show any affinity for LRP6, and for this reason, its function in Wnt signaling remains elusive [50]. Furthermore, a mouse study has revealed that both TCF1 and LEF1 contribute significantly to NK-cell development, and TCF1 plays a more prominent part in NK-cell development [51]. $\beta$-Catenin-deficient mice have a decreased number of NK cells in vivo as compared to the control-these data are suggestive of an important function of $\beta$-catenin, LEF1, and TCF1 in HSCs [52].

Moreover, CD1D-restricted NKT cells have a crucial role in tumor rejection and immune regulation and are dependent on the regulatory relation between LEF1 and the CD1D gene. A study on two leukemia cell lines-Jurkat cells (T lymphocytes) and K562 (myelogenous leukemia cell line) has unveiled the underlying mechanism of interaction in which LEF1 specifically binds to the CD1D promoter and regulates $C D 1 D$ expression [53]. Nevertheless, an activated NKT cell produces cytokines that can regulate other immune cells (DCs, NK cells, and T cells) surrounding the TME by secreting IL-4 and IFN $\gamma$ thereby implementing anti-tumor responses [54].

\subsubsection{Wnt Signaling in T cells}

$\mathrm{T}$ cells are a type of lymphocyte that, according to recent findings, have a significant function in $\mathrm{CD}^{+}$and $\mathrm{CD} 8^{+} \mathrm{T}$-cell-mediated adaptive immune responses. In the case of viral infection, naïve $\mathrm{T}$ cells trigger the formation of $\mathrm{T}$ effector cells that are detrimental to pathogens via cytotoxicity and also form memory $\mathrm{T}$ cells, which respond more efficiently to any future infection [55]. Memory $\mathrm{T}$ cells downregulate the activity of T effector cells in an antigen-independent manner by utilizing IL-7 and IL-15 [56]. On the contrary, in cancer, T cells become dysfunctional due to consistent exposure to an antigen in the TME and start to express inhibitory receptors, including LAG-3, Tim-3, CTLA-4, and PD-1 [57,58].

In $\mathrm{T}$ cell development and regulation, the contributing pathways include $\mathrm{Wnt} / \beta$-catenin, SMAD, signal transducer and activator of transcription 3 (STAT3), and Notch signaling pathways [59]. Nevertheless, the first evidence of the participation of Wnt signaling in the immune system originates from the studies on T-cell development in the thymus [3]. Wnt signaling has been reported to perform a significant function in thymopoiesis. During the initial phases of thymocyte development in mice, high-mobility group (HMG) transcription factors of the Wnt pathway (TCF1 and LEF1) are known to be essential for the regulation of thymocyte development and maturation $[60,61]$. Precursor T cells mature in the thymus, owing to the presence of Delta-like ligands for Notch, which is essential for T-cell development in humans and mice [62,63]. One of the downstream target genes of Notch signaling is TCF1, which subsequently restrains LEF1 to stop the transformation of thymocytes; in TCF1-deficient mice though, it stimulates T-lineage maturation [64]. By direct ablation of double-positive (DP) thymocytes, researchers have found that TCF1 and LEF1 deficiency diminishes the maturation of $\mathrm{CD}^{+} \mathrm{T}$ cells into the $\mathrm{CD} 8^{+}$cell lineage. Both TCF1 and LEF1 interact with $\beta$-catenin to regulate the $\mathrm{DP}\left(\mathrm{CD} 4^{+} \mathrm{CD}^{+}\right)$cell differentiation into $\mathrm{CD} 4^{+} \mathrm{T}$ cells, and in this process, Th-POK is an upstream regulator. In contrast, $\mathrm{CD} 8^{+} \mathrm{T}$-cell maturation and development are regulated by the crosstalk between TCF1 and RUNX3 serving to silence CD4 gene expression [65]. Histone deacetylases HDAC1 and HDAC2 and transcription factor Th-POK are reported to maintain the integrity of $\mathrm{CD} 4^{+} \mathrm{T}$ cells by repressing the genes associated with the $\mathrm{CD} 8^{+}$lineage $[66,67]$. Similarly, a study has revealed that Wnt transcription factor LEF1 and TCF1 are important for establishing CD8 ${ }^{+}$T-cell identity due to HDAC activity, by downregulating RAR-related orphan receptor C (RORC), forkhead box P3 (FOXP3), and CD4 in a mouse model [68]. Moreover, TCF1 has multiple isoforms in which it possesses a long chain of the $\beta$-catenin $\mathrm{N}$-terminal domain. The crosstalk between $\beta$-catenin and the long $\mathrm{N}$-terminal domain maintains thymocyte survival instead of thymic maturation as identified in TCF1 isoform-deficient $\left(\mathrm{p} 45^{-/-}\right.$) mice [69]. During thymopoiesis, the importance of $\beta$-catenin has been confirmed because it upregulates interleukin 7 receptor subunit $\alpha$ (IL7R- $\alpha$ ) in thymocytes through positive selection [70]. 
A study has shown that by means of soluble FZD-type receptors as a decoy, thymocyte development can be stopped in murine thymic organ culture possibly owing to the disruption of Wnt signaling [71]. Both TCF1 and LEF1 are necessary because targeted gene disruption completely blocks thymocyte differentiation. Similarly, in another study, double mutation LEF1 $1^{-/-} \mathrm{TCF}^{-/-}$in mice induced T-cell differentiation arrest at an immature $\mathrm{CD}^{+}$single-positive stage, in cells expressing T-cell receptor beta (TCR $\beta$ ) but with reduced TCR $\alpha$ gene transcription [72]. The transition of thymocytes from double-negative (DN) to DP is regulated by Wnt signaling. The expression of naturally occurring inhibitor of $\beta$-catenin and TCF (ICAT) blocks the thymocyte transition from the DN to DP stage, but does not have any effect on later developmental stages. On the contrary, DKK1 inhibits the binding of Wnt to co-receptors LRPs and stops the thymocyte differentiation in a dose-dependent manner at the $\mathrm{DN}$ stage [73,74]. As for $\beta$-catenin, its function in $\mathrm{CD} 8^{+} \mathrm{T}$ cells is to induce stem cell-like properties (self-renewal and differentiation into effector cells); similarly, TCF1 induces the same functionality in these cells, and silencing of its expression eliminates the stem cell-like properties from $\mathrm{CD}^{+} \mathrm{T}$ cells [75]. Accordingly, the Wnt $\beta$-catenin pathway positively correlates with the progression of a tumor and metastasis. It is a significant oncogenic pathway that induces immune evasion and is thereby negatively associated with the effector $\mathrm{CD} 8^{+} \mathrm{T}$ cell infiltration at the tumor site [59].

In a mouse model of lymphocytic choriomeningitis mammarenavirus chronic infection, among $\mathrm{CD}^{+} \mathrm{T}$ cells, memory cell (Th1, Tfh) production is regulated due to the presence of TCF1 long isoforms [76]. Moreover, the induction of the GATA-3-1b isoform by TCF1 affects the differentiation of Th2 cells, and its absence can protect mice from ovalbumin-induced asthma [77]. Wnt3a has been found to activate Th2-cell differentiation via $\beta$-catenin and special AT-rich sequence binding protein 1 (SATB1) [78]. In contrast, Th17 cells have been demonstrated to eliminate tumors and to express large amounts of TCF7 and $\beta$-catenin while manifesting the characteristics similar to those of early memory $\mathrm{CD}^{+} \mathrm{T}$ cells [79]. Microarray analysis of chemokine ligand CXCL has confirmed that the expression of Wnt5a in human $\mathrm{CD}^{+} \mathrm{T}$ cells is necessary for T-cell migration [80].

\subsubsection{Wnt Signaling in B cells}

The Wnt pathway is associated with the regulation of various essential cellular processes including lymphopoiesis, although its role in B cells is perhaps less understood, especially the role in B-cell progenitors in bone marrow as compared to Tcells in the thymus [3]. The early stage of B-cell growth is regulated by canonical and non-canonical Wnt pathways; however, its aberrant activation has oncogenic complications [81,82]. B-cell proliferation is regulated by Wnt signals through LEF1, and a study revealed that mice deficient in LEF1 have defects in pro-B-cell proliferation and survival both in vivo and in vitro. Due to increased $c-M y c$ and Fas transcription, the sensitivity to apoptosis is higher [83]. FZD9-/- mice have a defect in B-cell lymphopoiesis; this defect negatively affects B-cell development in bone marrow, especially in cycling pre-B cells [84]. Nonetheless, in the case of human B-cell progenitors, Wnt3a stimulation negatively affects the proliferation potential of B cells despite increased $\beta$-catenin levels [85]. Similarly, there is antagonism between canonical Wnt signaling and Wnt5a signals in the thymus because Wnt5a signals via noncanonical pathways, thereby inhibiting the proliferation of B cells in a cell-autonomous manner. On the other hand, the absence of the wild-type Wnt5a allele induces B-cell lymphomas and clonal myeloid leukemia in hemizygous mice. Wnt5a gene deletion or loss of its expression has been observed during the analysis of human primary leukemia [86]. Similarly, Hodgkin lymphoma (HL) originates from transformed Reed-Sternberg (RS) cells, which usually lack B-cell receptor expression [87]. Additionally, HL cell lines express other components of the Wnt pathway and increased levels of cytoplasmic and nuclear $\beta$-catenin $[88,89]$. Nevertheless, the activation of GSK-3 $\beta$ in classical HL (cHL) consequently inhibits Wnt- $\beta$-catenin signaling [90].

In a TME, aside from the production of cytokines and antibodies, B cells play a versatile role in the modulation of innate immune and T-cell responses [91]. By contrast, tumor-infiltrating B lymphocytes have been identified in solid tumors and play a significant role in cancer suppression by releasing immunoglobulins and activating $\mathrm{T}$ cells to directly kill cancer cells [92]. The expression of specific 
markers on different B-cell subtypes has contradictory effects on pro- or antitumorigenic processes. A recent study revealed that during an early phase of tumor progression, B cells produce antibodies that cause DCs and cytotoxic T cells to control tumor growth [93]. On the contrary, regulatory B cells promote a pro-tumorigenic response to facilitate tumor progression. Notably, a study has been performed on acute myeloid leukemia (AML) where B cells include a higher proportion of regulatory B cells and display surface markers CD19, CD24, and CD38 [94]. Nonetheless, less attention is given to the investigation of the role of Wnt signaling in B-cell development and regulation along with its participation in carcinogenesis. Therefore, further research is needed in the context of B cells to develop new treatment modalities for cancer.

\subsection{Wnt Signaling in Myeloid-Originated Immune Cells}

\subsubsection{Wnt Signaling in Macrophages}

Macrophages are essential for homeostasis in most of organ systems for tissue repair and development; additionally, these cells provide defense against pathogens, cancer, and chronic inflammation [95]. The involvement of macrophages in a diverse array of cellular functions gives these cells plasticity to adapt well to their microenvironment [96]. In many organs after tissue injury, macrophages establish a tissue repair program, and the associated Wnt ligands are essential players in tissue regeneration and fibrosis [97]. Wnt-specific ligands also play a regulatory part during infection or inflammation. It is speculated that in response to isolated TLR ligands, NF- $\mathrm{kB}$ activation, or Mycobacterium tuberculosis, macrophages express Wnt5a and its receptor FZD5 [98]. Similarly, the expression of Wnt5a and FZD5 has been observed in biopsy samples from patients with sepsis [99]. Another study revealed bacterial infection (with Francisella tularensis) in murine peritoneal macrophages that were caused by the activation of GSK3 $\beta$ both in vivo and in vitro. Inhibition of GSK3 $\beta$ leads to a noticeable reduction in the production of anti-inflammatory cytokines such as tumor necrosis factor $\alpha(\mathrm{TNF} \alpha)$, IL-12p40, and IL-6 [100]. According to these results, GSK3 $\beta$ acts as a regulator that modulates the inflammatory responses and could be harmful to the host during infection by F. tularensis, thereby pointing to novel therapeutic targets in tularemia. Macrophages and Wnt proteins are involved in cardiac repair as observed in mice after myocardial infarction [101]. A study on mice has revealed that the specific ablation of the Wntless (WLS) protein, which is essential for the secretion of Wnt ligands, improves heart function and cardiac repair after an ischemic injury caused by myocardial infarction [101]. These findings point to a potential therapeutic target for the improvement of cardiac repair via targeting of natural Wnt inhibitors. The intestinal stroma is mainly composed of macrophages, which have been found to perform a pivotal function in the coordination of intestinal repair because of the presence of macrophage-derived Wnt signaling. To further unravel the macrophage-derived Wnt signaling, porcupine $O$-acyltransferase (PORCN) depleted mice have been studied and show normal intestinal morphology but are hypersensitive to radiation injury as compared with wild-type littermates [102]. In acute murine colitis treated with 2,4,6-trinitrobenzene sulfonic acid, the STAT6-dependent macrophage phenotype mediates mucosal repair via activation of the Wnt signaling pathway [103]. In a STAT6 ${ }^{-/-}$murine model treated with 2,4,6-trinitrobenzene sulfonic acid, impaired wound healing was observed and yielded a reduction in mRNA expression of Wnt ligands (Wnt2b, Wnt7b, and Wnt10a) in cells of the lamina propria and mucosa [103]. Furthermore, Wnt7b has a repair function because its somatic deletion in macrophages negatively influences tissue repair and kidney regeneration after ischemic injury in a mouse model [104]. The expression of the Wnt7b protein in myeloid cells induces tumor progression, metastasis, angiogenesis, and enhances the functionality of tumor-associated macrophages (TAMs) in humans and mice. In myeloid cells in an MMTV-PyMT mouse model, Wnt7b gene deletion induces a dramatic reduction in mammary gland tumor volume and mass as compared to wild-type mice [105]. On the other hand, it has been reported that the induced expression of Wnt3a causes macrophages to engulf hepatocyte debris during liver regeneration [106]. This process activates the commitment of murine hyperspiny purkinje cells to the 
hepatocytes through the $\beta$-catenin-dependent pathway in a mouse model [106]. Wnt5a is important for macrophage-induced invasiveness because of its proteolytic activity, along with its ability to regulate tumor cell migration, insulin resistance, atherosclerosis, and obesity $[107,108]$.

A proinflammatory activity of Wnt5a in macrophages has been demonstrated too, after the identification and internalization of Chandipura virus or Escherichia coli by receptor CD14. The Wnt5a-FZD5-Rac1-p65 signaling cascade consequently activates TLR signaling in bone marrow-derived macrophages and in a murine macrophage (RAW 264.7) cell line [109]. Wnt5a induces a proinflammatory response not only during infection and organ repair or injury; for example, a study suggests that Wnt5a may activate an immunosuppressive response in macrophages in both humans and mice [110]. In humans, the differentiation into M1-type macrophages is inhibited via Wnt5a-induced suppression of the NF- $\mathrm{kB}$ pathway. Therefore, this triggers the production of immunosuppressive cytokines (e.g., TGF- $\beta$ and IL-10) and induces an M2 macrophage like phenotype [110]. The M2-like phenotype acquired by TAMs conducive to the production of inflammatory cytokines IL-23 and IL-17, which have been reported to positively promote tumor growth and progression [111]. Tumor cells have been demonstrated to reprogram macrophages into a distinct TAM population via the exosomal pathway. This pathway plays an important role in the transport of miR-1246 from P53-mutant colon cancer cells to peripheral macrophages-this process induces M0 and M2 macrophages to produce TGF- $\beta$, IL-10, VEGF, and CCL2 [112].

In brief, the actions of Wnt ligands in macrophages can significantly participate in the repair of tissue injury, although the reparative function is not universal. This is because not all Wnt ligands have the same biological activities and functions. Therefore, to obtain full mechanistic insight into each Wnt ligand's activity and its signaling components, additional studies are necessary, which will further clarify the participation of Wnt in various biological functions [110].

\subsubsection{Wnt Signaling in Granulocytes}

Granulocytes (mast cells, neutrophils, eosinophils, and basophils) contribute significantly to inflammation both in immune regulation and pathogen removal; they differentiate and mature in bone marrow before entering the blood circulation where they remain in the G0 phase in the absence of extracellular stimuli and undergo apoptosis $[113,114]$. As for Wnt signaling, it has been identified as a key process in the function of granulocytes. However, the mechanism is less studied. Moreover, neutrophils are among the first lines of defense because they are recruited to an area of infection or injury, and Wnt5a mediates this process [115]. By contrast, in eosinophils, Wnt5a in combination with other factors promotes cell proliferation, as observed in airway smooth muscle cells isolated from asthma patients [116]. Here, we briefly focus on mast cells.

Mast cells are the type of immune cells that reside in connective tissue throughout the body and significantly partake in the regulation of adaptive and innate immunity [117]. These cells originate from HSCs and differentiate within the tissue environment upon migration to peripheral tissues [118]. Nevertheless, an interesting similarity between mast cells and HSCs has been uncovered, including c-Kit expression and self-renewal. Wnt5a has been identified as a significant factor in this context because Wnt5a promotes the maturation of mast cells through the Wnt- $\beta$-catenin pathway [119]. Furthermore, mast cells contribute as a promoter and inhibitor of tumor growth, but the exact mechanism is not well understood [120]. The production of proangiogenic factors such as IL-8, TNF- $\alpha$, vascular endothelial growth factor (VEGF), basic fibroblast growth factor (bFGF), and transforming growth factor $\beta$ (TGF- $\beta$ ) promotes angiogenesis, whereas anticancer mediators include IL-1, IL-6, chymase, TNF- $\alpha$, and tryptase [120]. Further studies are needed to explore the activities of Wnt in granulocytes for the development of therapeutics.

\section{Wnt Signaling in Cancer}

Wnt signaling has been identified as a key player that governs several developmental and cellular processes such as cell proliferation, migration, and fate determination. Nonetheless, slight variation 
in this pathway could be detrimental by inducing cancer and therefore has been recognized as a key mechanism in cancer biology. There are several aberrant regulatory processes affecting Wnt signaling components, e.g., mutations, overexpression, and downregulation (Figure 3). There are numerous studies on the role of Wnt in cancer, however in this review we mainly focus on leukemia and breast, brain, and GCs.

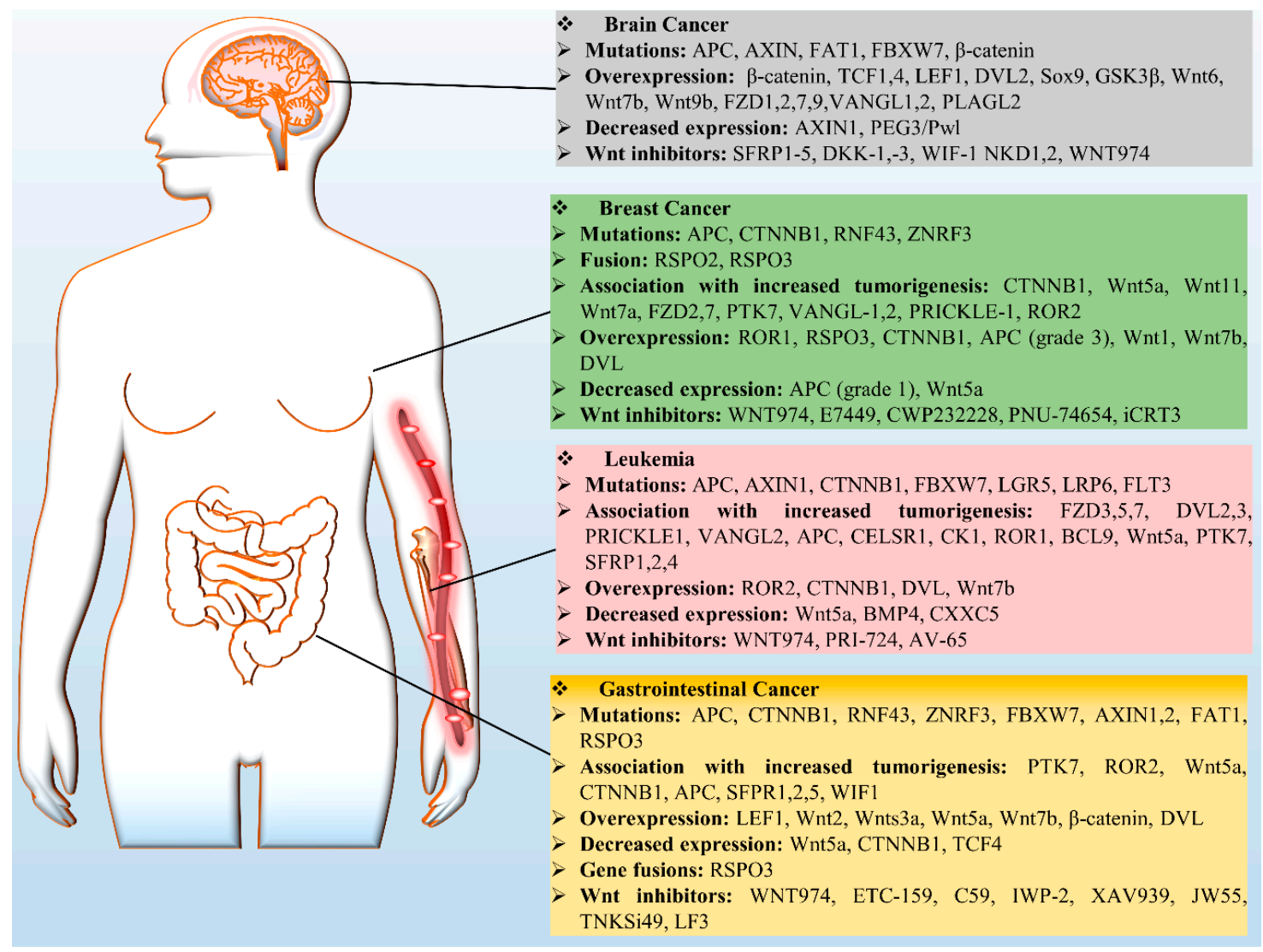

Figure 3. Wnt signaling in cancers. Deregulation of Wnt signaling components is involved in selected cancers (brain cancer, leukemia, breast cancer, and GCs) via a variety of mechanisms, including mutations, overexpression of Wnt proteins, decreased expression, gene fusion, and increased tumorigenesis; these data are summarized in the boxes. Protein symbols: BCL9, B-cell CLL or lymphoma 9; BMP4, bone morphogenetic protein 4; CELSR1, cadherin EGF LAG seven-pass G-type receptor 1; FBXW7, F-box and WD Repeat Domain -containing 7; FLT3, Fms-related tyrosine kinase 3; NKD1, naked cuticle homolog 1; PEG3/Pwl, paternally expressed 3; PLAG2, pleiomorphic adenoma-like protein 2; SFRP1, secreted frizzled-related protein 1; VANGL, Vang-like protein; WIF-1, Wnt-inhibitory factor 1.

\subsection{Breast Cancer}

Wnt signaling is activated in approximately $50 \%$ of breast tumors and is associated with reduced overall survival of the patients [121]. Wnt- $\beta$-catenin signaling is deeply involved in the initiation and progression of triple-negative breast cancer (TNBC) [122,123]. However, other breast cancer subtypes overexpress nuclear $\beta$-catenin [124]. Wnt signaling not only induces breast development during pregnancy, but also plays a crucial part in the oncogenic transformation of mammary tissue. The overexpression of FZD7 and Wnt7a is triggered by $\triangle N p 63$, which then activates stem cells that promote basal-like breast cancer [125]. The overexpression of R-spondin 2 initiates mammary tumors in mouse models [126]. Furthermore, ROR1 is not present in normal mammary tissue, but is overexpressed in breast cancer cells. Thus, it leads to rapid epithelial-mesenchymal transition and is linked to a low survival rate [127]. The up-regulation of PD-L1 in TNBC cancer stem cells is therefore associated with Wnt gene activation. Furthermore, clinical dataset analysis has revealed 
PD-L1 overexpression in TNBC tumors: a tradeoff between more enriched stem cells and enhanced Wnt activity $[128,129]$.

Besides, further updates have uncovered a relationship between resistance to a PI3K inhibitor and the upregulation of the canonical Wnt pathway-these phenomena are associated with poor prognosis among breast cancer patients [130]. Additionally, Wnt1-inducible signaling pathway protein 1 (WISP1) can transcriptionally block N-Myc downstream-regulated gene 1 (NDRG1) resulting in breast cancer metastasis [131]. Wnt pathway-driven processes can cause population heterogeneity of mammary breast cancer cells, among which the luminal subtype secretes Wnt1, which is essential for the propagation of a tumor and for cancer recurrence [132]. Nevertheless, deficiency of LRP5 results in a delay in Wnt1-triggered tumorigenesis followed by a reduction in progenitor cell accumulation [133]. On the other hand, DKK1 or DKK3 deficiency induces the self-renewal of progenitor cells by initiating the $\beta$-catenin pathway [134]. In human breast cancer, the $\mathrm{CD} 44^{(+)} \mathrm{CD} 24^{(- \text {low })}$ lineage shows high tumorigenicity, and both canonical and noncanonical Wnt signaling plays a crucial role in the implementation of epithelial-mesenchymal transition (EMT) and in the stem cell phenotype [135].

A Wnt pathway crosstalk is substantial in breast cancer; for example, in the Hippo pathway, a transcriptional coactivator called WW domain binding protein 2 (WBP2) forms a network with YAP, TAZ, and $\beta$-catenin, which then promotes TCF-induced malignancy [136]. These findings suggest that the presence of a polyclonal cell population in mammary tumors is due to Wnt activity in a specific subpopulation.

\subsection{Leukemia}

In recent years, it has become clear from various findings that the disruption of the Wnt pathway is important for the progression of hematological cancers [137]. Normal HSCs rely on the controlled regulation of Wnt signaling because it is a critical regulator of differentiation and self-renewal, whereas increased Wnt pathway activity is found in major leukemia [22]. AML is one of the most common leukemia with balanced translocations $t(8 ; 21)$ [138]. In AML, galectin-9-induced autocrine T-cell immunoglobulin mucin-3 (TIM-3) signaling stimulates LRP6 signalosome formation and the accumulation of $\beta$-catenin in the nucleus [139]. Accordingly, exosomes extracted from the plasma of AML patients show high levels of TGF- $\beta 1$ and suppress NK-associated cytotoxicity [140]. Notably, tumor-derived exosomes are critically involved in the suppression of immune cells by utilizing CD8+ anti-tumor effector cells. An exosomal profile can be used for disease prognosis and facilitates the characterization of a therapeutic outcome.

In mixed-lineage leukemia fusion positive mouse model, HSCs give rise to myeloid progenitor cells and leukemia-initiating cells (LICs) after progression via pre-LIC state $[141,142]$. $\beta$-Catenin is crucial for the progression from a pre-LIC to the LIC state and for the self-renewal of LICs [141,143]. Chromosomal aberrations affect canonical Wnt signaling because of frequent AML translocations (PML-RAR $\alpha$, AML1-ETO, and mixed-lineage leukemia [MLL]-AF9), which have been identified in derived cell lines and clinical samples $[142,144,145]$. The crosstalk of Wnt and NOTCH also promotes leukemic transformation of HSCs because of an interaction of $\beta$-catenin with forkhead box protein O1 (FoxO1) in osteoblasts which upregulates jagged1 [146].

The most common type of childhood leukemia is acute lymphoblastic leukemia (ALL), where bone marrow is infiltrated by immature lymphoblasts expressing T-cell immunophenotypic surface markers [147]. As for T cells, in ALL, most LICs harbor mutations that activate the Notch signaling pathway. Furthermore, the presence of canonical Wnt signaling in thymocytes and HSCs along with $c-M y c$ amplification induces $\beta$-catenin-dependent and Notch-independent activation of T-cell acute lymphoblastic leukemia (T-ALL) [148,149]. In Notch1-induced T-cell leukemia, the presence of high proportions of leukemic stem cells correlates with activated Wnt signaling [150]. Canonical Wnt signaling not only specifically induces tumorigenesis in T-ALL subsets but also takes part in LIC self-renewal. A study on a mouse model of Notch1-mediated T-ALL confirms that LICs feature increased Wnt activity and genetic inactivation of $\beta$-catenin causes a reduction in the number of LICs in these tumors [150]. 
Chronic lymphocytic leukemia (CLL) is the most common hematological cancer and is characterized by the accumulation of dysfunctional but morphologically mature CD5+ cells [151]. In CLL cells, canonical Wnt signaling is active, whereas its inhibition induces apoptosis in vitro [152]. Apart from the silencing by a Wnt-inhibiting factor, such as DKK1 or DKK2 [153], the mutation in a Wnt pathway-associated gene (for example BCL9 or FZD5) accounts for $14 \%$ of studied cases [154]. The overexpression of Wnt3, Wnt5b, Wnt6, Wnt10a, Wnt14, Wnt16, LRP5 and LRP6, LEF1, ROR1, or receptor FZD3 in CLL has been reported, contrary to normal B cells $[152,155,156]$. These findings validate our notion that the survival of CLL cells relies on active Wnt signaling. Moreover, the exosomes surrounding a CLL cell microenvironment contain noncoding Y RNA hY4 in abundance. These exosomes can be utilized by monocytes to activate the TLR cascade and secrete large amounts of CCL2, CCL4, IL-6, and PD-L1 to promote CLL progression [157].

Multiple myeloma has been characterized as the second most common hematological cancer associated with the aberrant Wnt signaling. Nonetheless, no oncogenic Wnt pathway mutation has been identified, indicating Wnt signaling stimulation in an autocrine or paracrine manner in a bone marrow microenvironment [158]. In hematological cancers, the cross-talk between innate and adaptive immunity is critical [159], and a deep understanding of this relation will facilitate the development of new therapeutics. In major leukemia, the presence of active canonical Wnt signaling is important for tumor initiation, progression, maintenance, and for the survival of LICs.

\subsection{Gastrointestinal Cancers (GCs)}

These cancers are among the most prevalent malignant tumors worldwide and are a prominent cause of cancer-related deaths [160]. The causative mutations found in the majority of colorectal tumors are associated with the following pathways: Wnt, TP53, PI3K, MAPK, and TGF- $\beta$ [161,162]. Accordingly, other mutations in the Wnt pathway are also associated with CRC, including transcription factor 7-like 2 (TCF7L2), Wilms tumor gene (FAM123B), and CTNNB1 [163,164]. The mutation driving Wnt signaling in CRC is the loss of the APC gene [165]. The oncogenesis of CRC can be modeled ex vivo in human-engineered intestinal organoids by means of the genome-editing CRISPR/Cas 9 technology [166,167]. Moreover, studies on CRC tumors have uncovered different APC mutations at specific levels of the canonical Wnt pathway, and these mutations are associated with particular tumor locations within the proximity of the large intestine $[168,169]$. CRC cells can regain their normal function upon a reversible knockdown of APC with short hairpin RNA [170]. In contrast, exosome-mediated communication in the TME also promotes tumor progression. Patients with colon cancer show a higher concentration of miR-203 in plasma exosomes, which triggers the differentiation of monocytes into M2-TAMs, consequently providing a favorable environment for tumor progression [171]. Accordingly, TAMs are regulated by tumor-derived exosomes, which influence host immune function and promote tumor spread to distant organs.

Hepatocellular carcinomas primarily harbor a missense mutation or insertions/deletions within CTNNB1 exon 3, thereby inducing defects in the production of $\beta$-catenin, which remains hypophosphorylated at Thr41, Thr45, Ser33, and Ser37 and hence is undegradable [165]. Helicobacter pylori infection is another major causative factor of GCs because it promotes Wnt- $\beta$-catenin signaling by activating cytotoxin-associated gene A (CagA), which induces cancer stem cell-like characteristics in GCs as $\beta$-catenin specifically binds to the promoter regions of OCT4 and NANOG [172]. Additionally, H. pylori-induced human GC is also associated with SOX9 expression, which eventually makes cancer cells responsive to $\beta$-catenin-dependent signaling [173]. Erythropoietin-producing hepatoma receptor A2 (EphA2) has been reported to enhance $\beta$-catenin nuclear localization and induces $c-M y c$ transcription, whereas Dv12 mediates EphA2-axin1 signaling by interacting with the tyrosine domain of EphA2 in GC cells [174]. Noncanonical signaling through Wnt5a also substantially partakes in GC progression: leucine-rich DVL associated protein mediates Wnt5a-triggered laminin $\gamma 2$ expression via JNK and Rac1 stimulation [175]. 
The activation of Wnt signaling has been detected in cholangiocarcinoma, and the validated mutations identified so far are an inhibitory ring finger protein 43 (RNF43) mutation, overexpression of Wntless, and hypermethylation of secreted frizzled-related protein 2 (SFRP2) [176-178]. Furthermore, osteopontin, a chemokine-like glycoprotein, has been found to enhance Wnt signaling in cholangiocarcinoma upon activation of the MEK-MAPK1 pathway via Ser675 phosphorylation and nuclear localization of $\beta$-catenin [179]. Wnt-secreting macrophages are present around the TME to maintain strong Wnt signaling $[180,181]$. The activity of SFRP2, a Wnt signaling inhibitor, is silenced in cholangiocarcinoma because of the hypermethylation of its gene $[178,182]$. Recently, immunohistochemical analysis was performed to evaluate the expression of FZD5, CK1, Wnt5a, axin, GSK3 $\beta$, ubiquitin, $c-M y c$, and cyclin D1-the results obtained are still unclear. Nonetheless, higher expression of components of the canonical Wnt pathway has been identified in samples of human gastric carcinomas [183].

\subsection{Brain Cancer}

The Wnt- $\beta$-catenin signaling pathway contributes significantly to various stages of brain development and remains crucial in the adult brain [184]. In neuro-oncology research, the mechanism of the Wnt pathway at a molecular level has piqued much interest among investigators. Wnt signaling controls and regulates anterior-posterior axis formation and neural differentiation during early vertebrate development [185]. By contrast, abnormal Wnt signaling in neural stem cells (NSCs) stimulates malignant transformation and initiates the formation of brain tumors [186]. For example, the prolonged activation of $\beta$-catenin augments neural progenitor cell proliferation in vivo, whereas its deletion reduces their proliferative capacity $[187,188]$. Additionally, Wnt3a upregulates Wnt signaling, and thus the clonogenic potential of NSCs increases [186]. Glioblastoma multiforme (GBM) is among the most lethal and common central-nervous-system tumors. GBM is resistant to treatment because it is distinguished by enhanced cell proliferation and extensive angiogenesis. The prevalent mutation characterized in GBM is homozygous deletion of FAT atypical cadherin 1 (FAT1), which initiates the upregulation of Wnt signaling in glioma. Similarly, another known feature of the GBM pathogenesis is the overexpression of the hepatocyte growth factor (HGF) pathway [189-192]. The data obtained within The Cancer Genome Atlas Program revealed that FAT1-inactivating mutations account for 1\% of GBM cases, whereas approximately $20 \%$ of the cases are reported to be related to a copy number loss of FAT1 in GBMs. In addition to genetic aberrations, epigenetic alterations have been observed too, for instance, the hypermethylation of $S F R P 1, S F R P 2$, and naked 2 (NKD2) has been characterized and is present in more than $40 \%$ of primary-GBM specimens [193]. Moreover, abnormality of the SFRP gene expression is associated with the downregulation of matrix metalloproteinase 2 (MMP-2) and affects GBM cell motility [194,195]. The overexpression of pleomorphic adenoma gene-like 2 (PLAGL2) suppresses the activity of glioma-initiating cells and NSCs while stimulating their self-renewal potential. Furthermore, transcriptomic data suggest that the differentiation-suppressive effect is associated with PLAGL2 owing to variation in Wnt pathway components (Wnt6, FZD2, and FZD9) [196].

It is well known that Wnt signaling makes a significant contribution to the progression and regulation of characteristics of brain-associated cancers, and further insight into the molecular mechanism will help to explore the oncogenic effects of this pathway.

\section{Therapeutic Targets in the Wnt Signaling Pathway}

In the past, several studies have shown that the aberrant regulation of the Wnt signaling pathway is responsible for the initiation and progression of various immune disorders and cancers, e.g., osteoarthritis, asthma, and CRC in addition to prostate, lung, breast, and thyroid cancer, and CLL $[2,159,197,198]$. Accordingly, several studies are underway to identify therapeutic targets in the Wnt signaling pathway and to devise new therapies that either antagonize intracellular signaling or block extracellular signals by means of kinase inhibitors, (e.g., small-molecule inhibitors, antibodies, antagonists, or peptides; Table 1). With respect to therapeutic targets, Wnt signaling antagonists are 
classified into four major classes: ligand/receptor inhibitors, PORCN inhibitors, tankyrase (TNKS) inhibitors, and $\beta$-catenin inhibitors.

As for Wnt signaling, ligand/receptor-targeted drugs binding to ligands or transmembrane proteins represent the main therapeutic approaches that are evaluated in clinical studies on various diseases, cancer in particularl. A large number of drugs are reported, and most of them are monoclonal antibodies (moAbs) such as vantictumab (anti-FZD1, anti-FZD2, anti-FZD5, anti-FZD7, and anti-FZD8) [199], IgG-2919 (anti-FZD5) [200], OTSA101 (an anti-FZD10 antibody-drug conjugate [ADC]) [201], MC-Val-Cit-PAB-MMAE (anti-LGR5 ADC) [202], cirmtuzumab (anti-ROR1) [203], PF-06647020 (anti-PTK7 ADC) [204], OMP-131R10 (anti-RSPO3) [205], sclerostin [206], OMP-54F28 (anti-FZD8) [207], and ROR1 chimeric antigen receptor (CAR) T cells. All these therapeutics are classified as Wnt ligand/receptor-targeted drugs [208]. PORCN is a key regulator of the Wnt signaling pathway and takes part in the palmitoylation and secretion of Wnt ligands in the endoplasmic reticulum. PORCN inhibitors show promise for the suppression of Wnt signaling and for the treatment of various cancers by blocking the secretion and oligomerization of Wnt receptors [209,210]. Several small-molecule PORCN inhibitors are being tested in clinical trials including LGK974 (WNT974) [211], inhibitor of Wnt production-2 (IWP-2) [212], WNT-C59 (C59) [213], RXC004 [214], and ETC-159 (ETC-1922159; Table 1) [215].

Moreover, the inhibitor IWP-2 is proposed for the treatment of cancer, especially CRC due to RNF43 mutations, whereas PORCN inhibitors WNT974 and ETC-159 are applicable to cancer stem cells $[200,211,216]$. Recent studies show that PORCN inhibitor RXC004 strongly increases the effectiveness of immuno-oncology agents such as anti-PD-1 checkpoint inhibitors and enhances immune responses [214]. Nevertheless, several important features need to be considered for future therapeutics, for example, the global blockage of all Wnt secretion, which will undermine gut homeostasis and the effects of canonical and noncanonical Wnt signaling [217,218].

Table 1. Therapeutic targets and inhibitors that are evaluated in clinical studies regarding cancers and Wnt signaling.

\begin{tabular}{|c|c|c|c|c|c|c|}
\hline Target & $\begin{array}{l}\text { Compound } \\
\text { Name }\end{array}$ & Cancer Model & Description & $\begin{array}{l}\text { Activity } \\
\text { (IC50) }\end{array}$ & $\begin{array}{l}\text { Clinical } \\
\text { Phase }\end{array}$ & $\begin{array}{c}\text { Reference/ } \\
\text { Clinicaltrials.gov }\end{array}$ \\
\hline & & & Small-molecule compounds & & & \\
\hline \multirow{13}{*}{ PORCN } & \multirow{6}{*}{$\begin{array}{l}\text { WNT974 } \\
\text { (LGK974) }\end{array}$} & $\begin{array}{l}\text { BRAF mutant } \\
\text { colorectal cancer }\end{array}$ & $\begin{array}{c}\text { In combination with cetuximab } \\
\text { and LGX818 }\end{array}$ & $0.4 \mathrm{nM}$ & $\mathrm{Ib} / \mathrm{II}$ & NCT02278133 \\
\hline & & $\begin{array}{l}\text { Primary ovarian cancer } \\
\text { (OV-7 and OV-14 } \\
\text { cell lines) }\end{array}$ & $\begin{array}{l}\text { In combination with } \\
\text { carboplatin }\end{array}$ & $\begin{array}{l}1.14 \mu \mathrm{M} \\
1.76 \mu \mathrm{M}\end{array}$ & NA & [219] \\
\hline & & $\begin{array}{c}\text { Head and neck } \\
\text { squamous carcinoma }\end{array}$ & Reduced axin 2 mRNA level & $0.3 \mathrm{nM}$ & II & NCT02649530 \\
\hline & & $\begin{array}{l}\text { Triple-negative breast } \\
\text { cancer }\end{array}$ & $\begin{array}{c}\text { In combination with buparlisib. } \\
\text { Dual targeting of the PI3K and } \\
\text { Wnt pathways }\end{array}$ & NA & \multirow{3}{*}{ I } & \multirow[t]{3}{*}{$\begin{array}{l}\text { NCT01351103 } \\
\text { [220-222] }\end{array}$} \\
\hline & & Melanoma & Antitumor activity & NA & & \\
\hline & & $\begin{array}{c}\text { Pancreatic } \\
\text { adenocarcinoma }\end{array}$ & $\begin{array}{c}\text { Reduces the expression of } \\
\text { Axin2 }\end{array}$ & NA & & \\
\hline & \multirow[b]{2}{*}{$\begin{array}{c}\text { ETC-159 } \\
(\text { ETC-1922159) }\end{array}$} & Solid tumors & Induces tumor regression & NA & I & NCT02521844 \\
\hline & & $\begin{array}{l}\text { Colorectal cancer with } \\
\text { R-Spondin } \\
\text { translocations }\end{array}$ & $\begin{array}{l}\text { Prevents tumor regrowth by } \\
\text { inducing irreversible cellular } \\
\text { differentiation }\end{array}$ & $2.9 \mathrm{nM}$ & Preclinical & [215] \\
\hline & \multirow{3}{*}{$\begin{array}{l}\text { C59 (WNT } \\
\text { C59) }\end{array}$} & $\begin{array}{l}\text { Mammary tumors in } \\
\text { mice }\end{array}$ & $\begin{array}{l}\text { Inhibits Wnt-1-promoted } \\
\text { tumor growth in mice }\end{array}$ & $74 \mathrm{pM}$ & Preclinical & [213] \\
\hline & & $\begin{array}{l}\text { Nasopharyngeal } \\
\text { carcinoma in mice }\end{array}$ & $\begin{array}{l}\text { Inhibits NPC subcutaneous } \\
\text { tumor growth }\end{array}$ & NA & NA & [223] \\
\hline & & $\begin{array}{l}\text { Intestinal neoplasia in } \\
\text { mice }\end{array}$ & $\begin{array}{l}\text { Inhibits RNF43 \& ZNRF43 } \\
\text { mutant intestinal epithelium }\end{array}$ & NA & NA & [224] \\
\hline & IWP-2 & Colorectal cancer & $\begin{array}{l}\text { Suppression of Wnt ligand } \\
\text { production }\end{array}$ & $27 \mathrm{nM}$ & Preclinical & {$[212,225]$} \\
\hline & RXC-004 & Solid tumors & Reduces tumor sizes & NA & NA & [214] \\
\hline
\end{tabular}


Table 1. Cont

\begin{tabular}{|c|c|c|c|c|c|c|}
\hline Target & $\begin{array}{l}\text { Compound } \\
\text { Name }\end{array}$ & Cancer Model & Description & $\begin{array}{l}\text { Activity } \\
\text { (IC50) }\end{array}$ & $\begin{array}{l}\text { Clinical } \\
\text { Phase }\end{array}$ & $\begin{array}{c}\text { Reference/ } \\
\text { Clinicaltrials.gov }\end{array}$ \\
\hline \multirow{14}{*}{ TANKs } & \multirow{4}{*}{ XAV939 (XAV) } & Colorectal cancer & $\begin{array}{l}\text { Induces axin stabilization and } \\
\text { inhibits colony formation of } \\
\text { DLD-1 cells }\end{array}$ & $\begin{array}{c}11 \mathrm{nM} \\
(\mathrm{TNKS} 1), 4 \\
\mathrm{nM}(\mathrm{TNKS} 2)\end{array}$ & \multirow{4}{*}{ Preclinical } & [226] \\
\hline & & Prostate cancer & $\begin{array}{c}\text { Attenuates } \beta \text {-catenin } \\
\text { translocation to the nucleus }\end{array}$ & NA & & [227] \\
\hline & & Breast cancer cells & $\begin{array}{l}\text { Decreases Wnt-3a promoted } \\
\text { cell migration in } \\
\text { MDA-MB-231 cells }\end{array}$ & $1.5 \mu \mathrm{M}$ & & [228] \\
\hline & & Lung adenocarcinoma & $\begin{array}{l}\text { Attenuated the colony } \\
\text { formation, proliferation, and } \\
\text { migration of A549 cells }\end{array}$ & NA & & [229] \\
\hline & \multirow[t]{2}{*}{ E7449 (2X-121) } & $\begin{array}{l}\text { Advanced ovarian } \\
\text { cancer }\end{array}$ & Anti-tumor activity & $50-100 \mathrm{nM}$ & II & NCT03878849 \\
\hline & & $\begin{array}{l}\text { Triple-negative breast } \\
\text { cancer }\end{array}$ & $\begin{array}{l}\text { In combination with } \\
\text { carboplatin and paclitaxel }\end{array}$ & NA & NA & NCT01618136 \\
\hline & AZ1366 & $\begin{array}{l}\text { Non-small cell lung } \\
\text { cancer }\end{array}$ & $\begin{array}{l}\text { Decreases tumor growth in } \\
\text { combination with gefitinib }\end{array}$ & NA & Preclinical & [230] \\
\hline & JW55 & Colorectal cancer & $\begin{array}{l}\text { Reduces Wnt signaling and } \\
\text { tumor cell growth in } \\
\text { SW } 480 \text { cells }\end{array}$ & $\begin{array}{c}1.9 \mu \mathrm{M} \\
(\mathrm{TNKS} 1) \\
0.83 \mu \mathrm{M} \\
\text { (TNKS2) }\end{array}$ & Preclinical & [231] \\
\hline & NVP-TNKS656 & Colorectal cancer & $\begin{array}{l}\text { Suppresses cancer growth in } \\
\text { APC-mutant Patient-derived } \\
\text { xenograft models }\end{array}$ & $\begin{array}{c}6 \mathrm{nM} \\
(\mathrm{TNKS} 2)\end{array}$ & Preclinical & [232] \\
\hline & GOO7-LK & Colorectal cancer & $\begin{array}{l}\text { Inhibits tumor growth in } \\
\text { APC-mutant CRC xenograft } \\
\text { models }\end{array}$ & $\begin{array}{c}46 \mathrm{nM} \\
(\mathrm{TNKS} 1), 25 \\
\mathrm{nM}(\mathrm{TNKS} 2)\end{array}$ & Preclinical & [233] \\
\hline & IWR-1 & Osteosarcoma & $\begin{array}{l}\text { Decreases tumor growth in } \\
\text { combination with doxorubicin }\end{array}$ & $0.18 \mu \mathrm{M}$ & Preclinical & {$[212,234]$} \\
\hline & JW74 & Colorectal cancer & $\begin{array}{c}\text { Downregulates Wnt target } \\
\text { genes }\end{array}$ & $790 \mathrm{nM}$ & Preclinical & [235] \\
\hline & TNKSi49 & Colorectal cancer & Suppresses tumor growth & $0.3 \mathrm{nM}$ & NA & [236] \\
\hline & WIKI4 & Multiple cell lines & Inhibits TNKS 2 activity & $\begin{array}{c}15 \mathrm{nM} \\
\text { (TNKS2) }\end{array}$ & NA & [237] \\
\hline \multirow{13}{*}{$\beta$-Catenin } & \multirow{4}{*}{$\begin{array}{l}\text { PRI-724 } \\
\text { (ICG-001) }\end{array}$} & Pancreatic cancer & Inhibits tumor growth & $3 \mu \mathrm{M}$ & $\mathrm{Ib}$ & NCT01764477 \\
\hline & & Osteosarcoma & $\begin{array}{l}\text { Attenuates cell proliferation in } \\
143 \mathrm{~B} \text { and SJSA-1 cells }\end{array}$ & NA & Preclinical & [238] \\
\hline & & $\begin{array}{c}\text { Acute myeloid } \\
\text { leukemia and Chronic } \\
\text { myeloid leukemia }\end{array}$ & Inhibits metastasis & NA & $\mathrm{I} / \mathrm{II}$ & NCT01606579 \\
\hline & & Colorectal cancer & $\begin{array}{l}\text { In combination with } \\
\text { mFOLFOX6 and bevacizumab }\end{array}$ & NA & II & NCT02413853 \\
\hline & CWP232228 & Breast cancer stem cells & $\begin{array}{l}\text { Inhibits tumor growth by } \\
\text { attenuating } \beta \text {-catenin-driven } \\
\text { transcription }\end{array}$ & $0.8 \mu \mathrm{M}$ & Preclinical & [239] \\
\hline & $\begin{array}{l}\text { CWP232291 } \\
\text { (CWP 291) }\end{array}$ & $\begin{array}{c}\text { Acute myeloid } \\
\text { leukemia and chronic } \\
\text { myeloid leukemia }\end{array}$ & Induces $\beta$-catenin degradation & $273 \mathrm{nM}$ & I & $\begin{array}{c}\text { NCT01398462 } \\
{[240]}\end{array}$ \\
\hline & \multirow{2}{*}{$\begin{array}{c}\text { BC2059 } \\
\text { (Tegavivint) }\end{array}$} & $\begin{array}{l}\text { Acute myeloid } \\
\text { leukemia }\end{array}$ & Reduces $\beta$-catenin level & NA & Preclinical & [241] \\
\hline & & Desmoid tumor & $\begin{array}{l}\text { Primary or recurrent } \\
\text { desmoid tumor }\end{array}$ & NA & I & NCT03459469 \\
\hline & LF3 & Colorectal cancer & Reduces tumor growth & $<2 \mu \mathrm{M}$ & Preclinical & [242] \\
\hline & MSAB & Colorectal cancer & Induces $\beta$-catenin degradation & $<6 \mu \mathrm{M}$ & Preclinical & [243] \\
\hline & SAH-BCL9 & Colorectal cancer & $\begin{array}{l}\text { Inhibits tumor cell migration } \\
\text { and proliferation }\end{array}$ & $135 \mathrm{nM}$ & Preclinical & [244] \\
\hline & $\begin{array}{l}\text { 2,4-diamino- } \\
\text { quinazoline }\end{array}$ & Colorectal cancer & $\begin{array}{l}\text { Inhibits the } \beta \text {-catenin-TCF4 } \\
\text { pathway }\end{array}$ & $0.22 \mu \mathrm{M}$ & Preclinical & [245] \\
\hline & PNU-74654 & Breast cancer & $\begin{array}{l}\text { It enhances apoptosis and } \\
\text { reduces } \beta \text {-catenin } \\
\text { accumulation and cell } \\
\text { proliferation. Used in } \\
\text { combination with } \\
\text { 5-fluorouracil }\end{array}$ & $122 \mu \mathrm{M}$ & NA & [246] \\
\hline
\end{tabular}


Table 1. Cont.

\begin{tabular}{|c|c|c|c|c|c|c|}
\hline Target & $\begin{array}{l}\text { Compound } \\
\text { Name }\end{array}$ & Cancer Model & Description & $\begin{array}{l}\text { Activity } \\
\text { (IC50) }\end{array}$ & $\begin{array}{l}\text { Clinical } \\
\text { Phase }\end{array}$ & $\begin{array}{c}\text { Reference/ } \\
\text { Clinicaltrials.gov }\end{array}$ \\
\hline & iCRT3 & $\begin{array}{l}\text { Triple-negative breast } \\
\text { cancer }\end{array}$ & $\begin{array}{c}\text { Inhibits the } \beta \text {-catenin nuclear } \\
\text { activity }\end{array}$ & $8.2 \mathrm{nM}$ & Preclinical & [247] \\
\hline & PKF115-584 & & & $3.2 \mu \mathrm{M}$ & & \\
\hline & PKF118-310 & $\begin{array}{l}\text { Colorectal cancer, } \\
\text { Hepatocellular cancer }\end{array}$ & $\begin{array}{l}\text { Inhibits tumor cell proliferation } \\
\text { and disrupts } \beta \text {-catenin-Tcf } \\
\text { complex }\end{array}$ & $0.8 \mu \mathrm{M}$ & Preclinical & {$[248,249]$} \\
\hline & CGP049090 & & & $8.7 \mu \mathrm{M}$ & & \\
\hline & AV-65 & Multiple myelomas & $\begin{array}{l}\text { Inhibits the growth of MM cells } \\
\text { in the mouse model }\end{array}$ & NA & Preclinical & [250] \\
\hline & ССТ036477 & Colorectal cancer & $\begin{array}{l}\text { Inhibits tumor growth in } \\
\beta \text {-catenin mutant mice }\end{array}$ & NA & Preclinical & [251] \\
\hline DVI & $3289-8625$ & Prostate cancer & $\begin{array}{l}\text { Decreases tumor growth in } \\
\text { PC- } 3 \text { cells }\end{array}$ & $12.5 \mu \mathrm{M}$ & NA & [252] \\
\hline & FJ9 & $\begin{array}{l}\text { Lung cancer and } \\
\text { melanoma cells }\end{array}$ & Reduces tumor cell growth & $\mathrm{Ki}=29 \mu \mathrm{M}$ & NA & [253] \\
\hline & & & Antibodies & & & \\
\hline \multirow{9}{*}{ FZDs } & \multirow{2}{*}{$\begin{array}{l}\text { Vantictumab } \\
\text { (OMP18R5) }\end{array}$} & Breast cancer & In combination with Paclitaxel & \multirow{9}{*}{ NA } & \multirow{2}{*}{ I } & NCT01973309 \\
\hline & & Pancreatic cancer & $\begin{array}{c}\text { In combination with } \\
\text { nab-paclitaxel and gemcitabine }\end{array}$ & & & NCT02005315 \\
\hline & $\begin{array}{l}\text { FZD8CRD } \\
\text { (F8CRDhFc) }\end{array}$ & Teratocarcinomas & Inhibits tumor growth & & Preclinical & [254] \\
\hline & \multirow{3}{*}{$\begin{array}{l}\text { OMP-54F28 } \\
\text { (Ipafricept) }\end{array}$} & Ovarian cancer & $\begin{array}{l}\text { In combination with paclitaxel } \\
\text { and carboplatin }\end{array}$ & & \multirow{3}{*}{ I } & NCT02092363 \\
\hline & & Hepatocellular cancer & In combination with sorafenib & & & NCT02069145 \\
\hline & & Pancreatic cancer & $\begin{array}{c}\text { In combination with } \\
\text { nab-paclitaxel and gemcitabine }\end{array}$ & & & NCT02050178 \\
\hline & $\begin{array}{c}\text { IgG-2919 } \\
\text { (Anti-FZD5 } \\
\text { mAb) }\end{array}$ & Pancreatic cancer & Inhibits tumor growth & & Preclinical & [200] \\
\hline & $\begin{array}{l}\text { OTSA101 } \\
\text { (OTSA101- } \\
\text { DTPA-90Y) }\end{array}$ & Synovial sarcoma & \multirow{2}{*}{ Antitumor activity } & & I & $\begin{array}{l}\text { NCT01469975 } \\
{[201]}\end{array}$ \\
\hline & $\begin{array}{l}\text { MC-Val-Cit- } \\
\text { PAB-MMAE }\end{array}$ & Gastric cancer & & & Preclinical & [255] \\
\hline R-spondin3 & $\begin{array}{l}\text { OMP-131R10 } \\
\text { (Rosmantuzumab) }\end{array}$ & Colorectal cancer & Inhibits tumor growth & NA & I & $\begin{array}{l}\text { NCT02482441 } \\
{[256]}\end{array}$ \\
\hline
\end{tabular}

APC, Adenomatous polyposis coli; CRC, Colorectal cancer; DVL, Dishevelled; FZDs, Frizzleds; IC50, Inhibitory concentration; IWP, Inhibitors of WNT production; Ki, Kinetic Inhibitor; NA, Not applicable; NPC, Nasopharyngeal carcinoma; PI3K Pathway, Phosphoinositide 3-kinase pathway; PORCN, Porcupine; Rnf43, RING finger protein 43; TANKs, Tankyrases; TNBC, Triple-negative breast cancer; Znrf3, zinc RING finger protein 3.

The TNKS enzyme is a member of the poly (ADP ribose) polymerase (PARP) superfamily that adds ADP-ribose onto target proteins. TNKS inhibitors suppress PARylation and degradation of oncogenic signaling proteins such as axin, angiomotin (AMOT), phosphatase and tensin homolog (PTEN), and telomeric repeat-binding factor 1 (TRF1). As a result, the abundance of axin increases, and the overactivated destruction complex inhibits the WNT- $\beta$-catenin signaling pathway and telomere shortening and suppresses Yes-associated protein 1 (YAP)-dependent transcription, while PI3K signaling is repressed [257-259]. Wnt- $\beta$-catenin signaling is blocked by various TNKS inhibitors such as tankyrase inhibitor 49 (TNKSi49) [236], XAV939 [226], JW74 [260], AZ1366 [261], IWR-1 [234,262], NVP-TNKS656 [232], WIKI4 [237], G007-LK [233], and JW55 [231] in different tumor models. Additionally, TNKS inhibitors are effective in a combination therapy with inhibitors (API2) of AKT (also known as protein kinase B) or with a PI3K inhibitor (BKM120), MEK inhibitor (AZD6244), or an EGFR inhibitor (erlotinib or gefitinib); this combination therapy shows promise against the tumors where $\beta$-catenin is overexpressed $[230,232,263,264]$. Nevertheless, TNKS inhibitors have numerous substrates that are involved in important cellular processes like the regulation of telomere length, Wnt signaling, myelination, and lung fibrogenesis. Although the clinical effectiveness of TNKS inhibitors is high, this inhibition may have acute adverse effects, and these inhibitors have been delayed at the preclinical stage [265]. 
The interaction of $\beta$-catenin with transcription factors (TCF or LEF) is an irresistible therapeutic target; in particular, inhibition of $\beta$-catenin enhances its degradation and disrupts its binding to TCF or LEF [266]. There are many reported small-molecule compounds that antagonize protein-protein interactions such as, e.g., $\beta$-catenin-TCF, stabilized $\alpha$ helix of B-cell lymphoma 9 (SAH-BCL9) [244], BC-2059 [241], PRI-724 [267], CGP049090 [268], PKF115-584 [269], LF3 [242], CWP232228 [270], and MSAB [243]. Other than the above-mentioned compounds, a number of synthetic molecules such as inhibitors of catenin-responsive transcription (iCRT3, iCRT5, and iCRT14), PNU-74654, and BC21 have been identified by high-throughput screening and computational-docking studies [271-273]. Although these in silico and in vitro screening procedures produce a large number of molecules, the biological activity and binding mechanism for most of them are not clear [274]. Furthermore, there are numerous difficulties, for instance, the binding affinity of $\beta$-catenin for TCF is very strong $(20 \mathrm{nM})$, and the role of $\beta$-catenin in cell adhesion is unknown where there is an overlap of $E$-cadherin and TCF interaction sites [225]. Therefore, novel strategies are needed to overcome these hurdles and to target the interaction of $\beta$-catenin with various transcription cofactors.

There are several recently discovered therapeutic targets such as dickkopf family members (DKK1, DKK2, DKK3, and DKK4), which perform a significant function as immunomodulators in immune diseases (as discussed earlier) [275]. The DKK1 receptor and cytoskeleton-associated protein 4 (CKAP4) are expressed in tumor cells, suggesting that the inhibition of DKK family members and DKK1-CKAP4 interactions can be examined as a potential therapeutic target, but further studies are still needed to validate this approach [276].

\section{Conclusions and Future Directions of Research}

The Wnt signaling pathway plays an essential role in cell differentiation, division, and proliferation, as well as embryonic growth, stem cell development, tissue regeneration, and immune cell regulatory mechanisms [1,2]. In this review, we broadly discussed the participation of Wnt signaling in immune cell modulation and the aberrant regulation of Wnt pathway components in cancer and highlighted the relevant therapeutic targets. There are various mutations as well as the overexpression and downregulation of Wnt pathway components: These aberrations can be regarded as causes of immunological disorders and cancers. The role of Wnt signaling in immune cells is becoming an area of active research because of the significant participation of this pathway in the regulation of immune cells apart from cellular survival, proliferation, and development. The functions of Wnt signaling in immune cell-regulatory mechanisms are diverse, for example, the tolerogenic response among DCs, development of NK cells, thymopoiesis of T cells, and B-cell-driven initiation of T-cell activities and Wnt signaling in macrophages. These phenomena are involved in tissue repair, regeneration, and fibrosis $[3,26,46,97]$. Moreover, all these processes are intricate and lack mechanistic illustrative studies-this situation precludes the invention and formulation of therapeutic strategies and convolutes the outcomes of existing therapeutic modalities. By examining the underlying mechanisms, we revealed that targeting of Wnt signaling can probably overcome all the primary, adaptive, and acquired resistance to cancer immunotherapy.

Therefore, drug monotherapy is usually insufficient for defeating cancer owing to the complex signaling mechanisms and interactions of pathways. We would like to emphasize that combination therapy is expected to be highly useful for targeting Wnt signaling during cancer treatment in order to help clinicians to attain a successful result. Although there are several Wnt inhibitors that have been studied regarding cancer treatment, it would be worthwhile to extend this research to immune cells.

Author Contributions: M.H. conceptualized the review paper, M.H. and R.H.P. drafted the manuscript. Q.U.A. created the table. M.H. and S.C. created the figures. S.C. critically analyzed and coordinated the project. All authors read and approved the final manuscript.

Funding: National Research Foundation of Korea (NRF) grants No. NRF-2019M3A9A8065098, 2019M3D1A1078938, and 2019R1A6A1A11051471 (to S.C.), and a Ministry of Science and ICT grant (No. 2018K000369 to S.C.).

Conflicts of Interest: The authors declare that there are no competing interests. 


\section{Abbreviations}

$\begin{array}{ll}\text { APC } & \text { Adenomatous polyposis coli } \\ \beta \text {-catenin } & \text { Cadherin-associated protein } \beta \\ \text { CSCs } & \text { Cancer stem cells } \\ \text { CK1 } & \text { Casein kinase 1 } \\ \text { CCND1 } & \text { Cyclin D1 } \\ \text { CKAP-4 } & \text { Cytoskeleton-associated protein } 4 \\ \text { CaMKII } & \text { Calmodulin-dependent kinase II } \\ \text { CAR } & \text { Chimeric antigen receptor } \\ \text { DCs } & \text { Dendritic cells } \\ \text { Dvl/Dsh } & \text { Dishevelled } \\ \text { DKK1 } & \text { Dickkopf 1 } \\ \text { FZD } & \text { Frizzled } \\ \text { GSK3 } \beta & \text { Glycogen synthase kinase 3 } \beta \\ \text { iCRT } & \text { Inhibitors of catenin-responsive transcription } \\ \text { IP3 } & \text { Inositol 1,4,5-triphosphate } \\ \text { JNK } & \text { Jun N-terminal kinase } \\ \text { LRP5/6 } & \text { Lipoprotein receptor-related protein } 5 \text { or } 6 \\ \text { LEF } & \text { Lymphocyte-enhancer-binding factor } \\ \text { MEF2 } & \text { Myocyte enhancer factor 2 } \\ \text { moAbs } & \text { Monoclonal antibodies } \\ \text { NFAT } & \text { Nuclear factor of activated T cells } \\ \text { NLK } & \text { Nemo-like kinase } \\ \text { NK } & \text { Natural killer cells } \\ \text { PCP } & \text { Planar cell polarity } \\ \text { PTK7 } & \text { Protein tyrosine kinase 7 } \\ \text { PI3K-AKT } & \text { Phosphatidylinositol-3 kinases-AKT } \\ \text { PKC } & \text { Protein kinase C } \\ \text { PORCN } & \text { Porcupine O-acyltransferase } \\ \text { RYK } & \text { Tyrosine-protein kinase } \\ \text { ROR1/2 } & \text { Receptor tyrosine kinase-like orphan receptor 1 or 2 } \\ \text { Rac1 } & \text { Ras-related C3 botulinum toxin substrate 1 } \\ \text { RTKs } & \text { Receptor tyrosine kinases } \\ \text { RSPO3 } & \text { R-Spondin 3 } \\ \text { RNF43 } & \text { Ring Finger Protein 43 } \\ \text { TAMs } & \text { Tumor associated macrophages } \\ \text { TCF } & \text { T-cell factor } \\ \text { TNKS } & \text { Tankyrase } \\ \text { TRF1 } & \end{array}$

\section{References}

1. Barker, N. Adult intestinal stem cells: Critical drivers of epithelial homeostasis and regeneration. Nat. Rev. Mol. Cell Biol. 2014, 15, 19-33. [CrossRef] [PubMed]

2. Clevers, H.; Nusse, R. Wnt/beta-catenin signaling and disease. Cell 2012, 149, 1192-1205. [CrossRef] [PubMed]

3. Staal, F.J.; Luis, T.C.; Tiemessen, M.M. WNT signalling in the immune system: WNT is spreading its wings. Nat. Rev. Immunol. 2008, 8, 581-593. [CrossRef] [PubMed]

4. Gieseck, R.L., 3rd; Wilson, M.S.; Wynn, T.A. Type 2 immunity in tissue repair and fibrosis. Nat. Rev. Immunol. 2018, 18, 62-76. [CrossRef] [PubMed]

5. Nusse, R.; Clevers, H. Wnt/beta-Catenin Signaling, Disease, and Emerging Therapeutic Modalities. Cell 2017, 169, 985-999. [CrossRef] [PubMed]

6. MacDonald, B.T.; Tamai, K.; He, X. Wnt/beta-catenin signaling: Components, mechanisms, and diseases. Dev. Cell 2009, 17, 9-26. [CrossRef] 
7. Zhou, Y.; Nathans, J. Gpr124 controls CNS angiogenesis and blood-brain barrier integrity by promoting ligand-specific canonical wnt signaling. Dev. Cell 2014, 31, 248-256. [CrossRef]

8. Zhan, T.; Rindtorff, N.; Boutros, M. Wnt signaling in cancer. Oncogene 2017, 36, 1461-1473. [CrossRef]

9. Staal, F.J.; Arens, R. Wnt Signaling as Master Regulator of T-Lymphocyte Responses: Implications for Transplant Therapy. Transplantation 2016, 100, 2584-2592. [CrossRef]

10. Acebron, S.P.; Niehrs, C. beta-Catenin-Independent Roles of Wnt/LRP6 Signaling. Trends Cell Biol. 2016, 26, 956-967. [CrossRef]

11. Schlessinger, K.; Hall, A.; Tolwinski, N. Wnt signaling pathways meet Rho GTPases. Genes Dev. 2009, 23, 265-277. [CrossRef] [PubMed]

12. Famili, F.; Perez, L.G.; Naber, B.A.; Noordermeer, J.N.; Fradkin, L.G.; Staal, F.J. The non-canonical Wnt receptor Ryk regulates hematopoietic stem cell repopulation in part by controlling proliferation and apoptosis. Cell Death Dis. 2016, 7, e2479. [CrossRef] [PubMed]

13. Katoh, M. Canonical and non-canonical WNT signaling in cancer stem cells and their niches: Cellular heterogeneity, omics reprogramming, targeted therapy and tumor plasticity (Review). Int. J. Oncol. 2017, 51, 1357-1369. [CrossRef] [PubMed]

14. Yamaguchi, T.; Yanagisawa, K.; Sugiyama, R.; Hosono, Y.; Shimada, Y.; Arima, C.; Kato, S.; Tomida, S.; Suzuki, M.; Osada, H.; et al. NKX2-1/TITF1/TTF-1-Induced ROR1 is required to sustain EGFR survival signaling in lung adenocarcinoma. Cancer Cell 2012, 21, 348-361. [CrossRef] [PubMed]

15. Gong, B.; Shen, W.; Xiao, W.; Meng, Y.; Meng, A.; Jia, S. The Sec14-like phosphatidylinositol transfer proteins Sec14l3/SEC14L2 act as GTPase proteins to mediate $\mathrm{Wnt} / \mathrm{Ca}\left({ }^{2+}\right)$ signaling. Elife 2017, 6, e26362. [CrossRef]

16. Dejmek, J.; Safholm, A.; Kamp Nielsen, C.; Andersson, T.; Leandersson, K. Wnt-5a/Ca ${ }^{2+}$-induced NFAT activity is counteracted by Wnt-5a/Yes-Cdc42-casein kinase 1alpha signaling in human mammary epithelial cells. Mol. Cell. Biol. 2006, 26, 6024-6036. [CrossRef]

17. Sheldahl, L.C.; Park, M.; Malbon, C.C.; Moon, R.T. Protein kinase C is differentially stimulated by Wnt and Frizzled homologs in a G-protein-dependent manner. Curr. Biol. 1999, 9, 695-698. [CrossRef]

18. Huang, T.; Xie, Z.; Wang, J.; Li, M.; Jing, N.; Li, L. Nuclear factor of activated T cells (NFAT) proteins repress canonical Wnt signaling via its interaction with Dishevelled (Dvl) protein and participate in regulating neural progenitor cell proliferation and differentiation. J. Biol. Chem. 2011, 286, 37399-37405. [CrossRef]

19. Ishitani, T.; Kishida, S.; Hyodo-Miura, J.; Ueno, N.; Yasuda, J.; Waterman, M.; Shibuya, H.; Moon, R.T.; Ninomiya-Tsuji, J.; Matsumoto, K. The TAK1-NLK mitogen-activated protein kinase cascade functions in the Wnt-5a/Ca $\left({ }^{2+}\right)$ pathway to antagonize Wnt/beta-catenin signaling. Mol. Cell. Biol. 2003, 23, 131-139. [CrossRef]

20. Lejeune, S.; Huguet, E.L.; Hamby, A.; Poulsom, R.; Harris, A.L. Wnt5a cloning, expression, and up-regulation in human primary breast cancers. Clin. Cancer Res. 1995, 1, 215-222.

21. Dejmek, J.; Dejmek, A.; Safholm, A.; Sjolander, A.; Andersson, T. Wnt-5a protein expression in primary dukes B colon cancers identifies a subgroup of patients with good prognosis. Cancer Res. 2005, 65, 9142-9146. [CrossRef] [PubMed]

22. Lento, W.; Congdon, K.; Voermans, C.; Kritzik, M.; Reya, T. Wnt signaling in normal and malignant hematopoiesis. Cold Spring Harb. Perspect. Biol. 2013, 5, a008011. [CrossRef]

23. Pai, S.G.; Carneiro, B.A.; Mota, J.M.; Costa, R.; Leite, C.A.; Barroso-Sousa, R.; Kaplan, J.B.; Chae, Y.K.; Giles, F.J. Wnt/beta-catenin pathway: Modulating anticancer immune response. J. Hematol. Oncol. 2017, 10, 101. [CrossRef] [PubMed]

24. Swafford, D.; Manicassamy, S. Wnt signaling in dendritic cells: Its role in regulation of immunity and tolerance. Discov. Med. 2015, 19, 303-310. [PubMed]

25. Suryawanshi, A.; Tadagavadi, R.K.; Swafford, D.; Manicassamy, S. Modulation of Inflammatory Responses by Wnt/beta-Catenin Signaling in Dendritic Cells: A Novel Immunotherapy Target for Autoimmunity and Cancer. Front. Immunol. 2016, 7, 460. [CrossRef]

26. Zhou, J.; Cheng, P.; Youn, J.I.; Cotter, M.J.; Gabrilovich, D.I. Notch and wingless signaling cooperate in regulation of dendritic cell differentiation. Immunity 2009, 30, 845-859. [CrossRef]

27. Hong, Y.; Manoharan, I.; Suryawanshi, A.; Majumdar, T.; Angus-Hill, M.L.; Koni, P.A.; Manicassamy, B.; Mellor, A.L.; Munn, D.H.; Manicassamy, S. beta-catenin promotes regulatory T-cell responses in tumors by inducing vitamin A metabolism in dendritic cells. Cancer Res. 2015, 75, 656-665. [CrossRef] 
28. Hong, Y.; Manoharan, I.; Suryawanshi, A.; Shanmugam, A.; Swafford, D.; Ahmad, S.; Chinnadurai, R.; Manicassamy, B.; He, Y.; Mellor, A.L.; et al. Deletion of LRP5 and LRP6 in dendritic cells enhances antitumor immunity. Oncoimmunology 2016, 5, e1115941. [CrossRef]

29. Wang, B.; Tian, T.; Kalland, K.H.; Ke, X.; Qu, Y. Targeting Wnt/beta-Catenin Signaling for Cancer Immunotherapy. Trends Pharmacol. Sci. 2018, 39, 648-658. [CrossRef]

30. Xu, W.D.; Wang, J.; Yuan, T.L.; Li, Y.H.; Yang, H.; Liu, Y.; Zhao, Y.; Herrmann, M. Interactions between canonical Wnt signaling pathway and MAPK pathway regulate differentiation, maturation and function of dendritic cells. Cell. Immunol. 2016, 310, 170-177. [CrossRef]

31. Manicassamy, S.; Reizis, B.; Ravindran, R.; Nakaya, H.; Salazar-Gonzalez, R.M.; Wang, Y.C.; Pulendran, B. Activation of beta-catenin in dendritic cells regulates immunity versus tolerance in the intestine. Science 2010, 329, 849-853. [CrossRef] [PubMed]

32. Manoharan, I.; Hong, Y.; Suryawanshi, A.; Angus-Hill, M.L.; Sun, Z.; Mellor, A.L.; Munn, D.H.; Manicassamy, S. TLR2-dependent activation of beta-catenin pathway in dendritic cells induces regulatory responses and attenuates autoimmune inflammation. J. Immunol. 2014, 193, 4203-4213. [CrossRef] [PubMed]

33. Manicassamy, S.; Ravindran, R.; Deng, J.; Oluoch, H.; Denning, T.L.; Kasturi, S.P.; Rosenthal, K.M.; Evavold, B.D.; Pulendran, B. Toll-like receptor 2-dependent induction of vitamin A-metabolizing enzymes in dendritic cells promotes T regulatory responses and inhibits autoimmunity. Nat. Med. 2009, 15, 401-409. [CrossRef] [PubMed]

34. Qian, C.; Qian, L.; Yu, Y.; An, H.; Guo, Z.; Han, Y.; Chen, Y.; Bai, Y.; Wang, Q.; Cao, X. Fas signal promotes the immunosuppressive function of regulatory dendritic cells via the ERK/beta-catenin pathway. J. Biol. Chem. 2013, 288, 27825-27835. [CrossRef] [PubMed]

35. Capietto, A.H.; Kim, S.; Sanford, D.E.; Linehan, D.C.; Hikida, M.; Kumosaki, T.; Novack, D.V.; Faccio, R. Down-regulation of PLCgamma2-beta-catenin pathway promotes activation and expansion of myeloid-derived suppressor cells in cancer. J. Exp. Med. 2013, 210, 2257-2271. [CrossRef]

36. Jiang, A.; Bloom, O.; Ono, S.; Cui, W.; Unternaehrer, J.; Jiang, S.; Whitney, J.A.; Connolly, J.; Banchereau, J.; Mellman, I. Disruption of E-cadherin-mediated adhesion induces a functionally distinct pathway of dendritic cell maturation. Immunity 2007, 27, 610-624. [CrossRef]

37. Oderup, C.; LaJevic, M.; Butcher, E.C. Canonical and noncanonical Wnt proteins program dendritic cell responses for tolerance. J. Immunol. 2013, 190, 6126-6134. [CrossRef]

38. Zhao, F.; Xiao, C.; Evans, K.S.; Theivanthiran, T.; DeVito, N.; Holtzhausen, A.; Liu, J.; Liu, X.; Boczkowski, D.; Nair, S.; et al. Paracrine Wnt5a-beta-Catenin Signaling Triggers a Metabolic Program that Drives Dendritic Cell Tolerization. Immunity 2018, 48, 147-160.e7. [CrossRef]

39. Holtzhausen, A.; Zhao, F.; Evans, K.S.; Tsutsui, M.; Orabona, C.; Tyler, D.S.; Hanks, B.A. Melanoma-Derived Wnt5a Promotes Local Dendritic-Cell Expression of IDO and Immunotolerance: Opportunities for Pharmacologic Enhancement of Immunotherapy. Cancer Immunol. Res. 2015, 3, 1082-1095. [CrossRef]

40. Rabinovich, G.A.; Gabrilovich, D.; Sotomayor, E.M. Immunosuppressive strategies that are mediated by tumor cells. Annu. Rev. Immunol. 2007, 25, 267-296. [CrossRef]

41. Palucka, K.; Banchereau, J. Cancer immunotherapy via dendritic cells. Nat. Rev. Cancer 2012, 12, $265-277$. [CrossRef]

42. Liang, X.; Fu, C.; Cui, W.; Ober-Blobaum, J.L.; Zahner, S.P.; Shrikant, P.A.; Clausen, B.E.; Flavell, R.A.; Mellman, I.; Jiang, A. beta-catenin mediates tumor-induced immunosuppression by inhibiting cross-priming of CD8(+) T cells. J. Leukoc. Biol. 2014, 95, 179-190. [CrossRef] [PubMed]

43. Spranger, S.; Bao, R.; Gajewski, T.F. Melanoma-intrinsic beta-catenin signalling prevents anti-tumour immunity. Nature 2015, 523, 231-235. [CrossRef] [PubMed]

44. Suryawanshi, A.; Manicassamy, S. Tumors induce immune tolerance through activation of beta-catenin/TCF4 signaling in dendritic cells: A novel therapeutic target for cancer immunotherapy. Oncoimmunology 2015, 4, e1052932. [CrossRef] [PubMed]

45. Kerdidani, D.; Chouvardas, P.; Arjo, A.R.; Giopanou, I.; Ntaliarda, G.; Guo, Y.A.; Tsikitis, M.; Kazamias, G.; Potaris, K.; Stathopoulos, G.T.; et al. Wnt1 silences chemokine genes in dendritic cells and induces adaptive immune resistance in lung adenocarcinoma. Nat. Commun. 2019, 10, 1405. [CrossRef]

46. Grzywacz, B.; Kataria, N.; Kataria, N.; Blazar, B.R.; Miller, J.S.; Verneris, M.R. Natural killer-cell differentiation by myeloid progenitors. Blood 2011, 117, 3548-3558. [CrossRef] 
47. Valencia, J.; Hernandez-Lopez, C.; Martinez, V.G.; Hidalgo, L.; Zapata, A.G.; Vicente, A.; Varas, A.; Sacedon, R. Transient beta-catenin stabilization modifies lineage output from human thymic $\mathrm{CD} 34^{+} \mathrm{CD} 1 \mathrm{a}^{-}$progenitors. J. Leukoc. Biol. 2010, 87, 405-414. [CrossRef]

48. Ichii, M.; Frank, M.B.; Iozzo, R.V.; Kincade, P.W. The canonical Wnt pathway shapes niches supportive of hematopoietic stem/progenitor cells. Blood 2012, 119, 1683-1692. [CrossRef]

49. Colucci, F.; Caligiuri, M.A.; Di Santo, J.P. What does it take to make a natural killer? Nat. Rev. Immunol. 2003, 3, 413-425. [CrossRef]

50. Niehrs, C. Function and biological roles of the Dickkopf family of Wnt modulators. Oncogene 2006, 25, 7469-7481. [CrossRef]

51. Held, W.; Clevers, H.; Grosschedl, R. Redundant functions of TCF-1 and LEF-1 during T and NK cell development, but unique role of TCF-1 for Ly49 NK cell receptor acquisition. Eur. J. Immunol. 2003, 33, 1393-1398. [CrossRef] [PubMed]

52. Zhang, T.; Liu, S.; Yang, P.; Han, C.; Wang, J.; Liu, J.; Han, Y.; Yu, Y.; Cao, X. Fibronectin maintains survival of mouse natural killer (NK) cells via CD11b/Src/beta-catenin pathway. Blood 2009, 114, 4081-4088. [CrossRef] [PubMed]

53. Chen, Q.Y.; Zhang, T.; Pincus, S.H.; Wu, S.; Ricks, D.; Liu, D.; Sun, Z.; Maclaren, N.; Lan, M.S. Human CD1D gene expression is regulated by LEF-1 through distal promoter regulatory elements. J. Immunol. 2010, 184, 5047-5054. [CrossRef] [PubMed]

54. Nair, S.; Dhodapkar, M.V. Natural Killer T Cells in Cancer Immunotherapy. Front. Immunol. 2017, 8, 1178. [CrossRef] [PubMed]

55. Chae, W.J.; Bothwell, A.L.M. Canonical and Non-Canonical Wnt Signaling in Immune Cells. Trends Immunol. 2018, 39, 830-847. [CrossRef]

56. Cui, W.; Kaech, S.M. Generation of effector $\mathrm{CD}^{+} \mathrm{T}$ cells and their conversion to memory T cells. Immunol. Rev. 2010, 236, 151-166. [CrossRef] [PubMed]

57. Schietinger, A.; Philip, M.; Krisnawan, V.E.; Chiu, E.Y.; Delrow, J.J.; Basom, R.S.; Lauer, P.; Brockstedt, D.G.; Knoblaugh, S.E.; Hammerling, G.J.; et al. Tumor-Specific T Cell Dysfunction Is a Dynamic Antigen-Driven Differentiation Program Initiated Early during Tumorigenesis. Immunity 2016, 45, 389-401. [CrossRef]

58. Xia, A.; Zhang, Y.; Xu, J.; Yin, T.; Lu, X.J. T Cell Dysfunction in Cancer Immunity and Immunotherapy. Front. Immunol. 2019, 10, 1719. [CrossRef]

59. Gattinoni, L.; Zhong, X.S.; Palmer, D.C.; Ji, Y.; Hinrichs, C.S.; Yu, Z.; Wrzesinski, C.; Boni, A.; Cassard, L.; Garvin, L.M.; et al. Wnt signaling arrests effector T cell differentiation and generates CD8 ${ }^{+}$memory stem cells. Nat. Med. 2009, 15, 808-813. [CrossRef]

60. Ma, J.; Wang, R.; Fang, X.; Sun, Z. beta-catenin/TCF-1 pathway in T cell development and differentiation. J. Neroimmune Pharmacol. 2012, 7, 750-762. [CrossRef]

61. Steinke, F.C.; Xue, H.H. From inception to output, Tcf1 and Lef1 safeguard development of T cells and innate immune cells. Immunol. Res. 2014, 59, 45-55. [CrossRef] [PubMed]

62. Schmitt, T.M.; Zuniga-Pflucker, J.C. Induction of T cell development from hematopoietic progenitor cells by delta-like-1 in vitro. Immunity 2002, 17, 749-756. [CrossRef]

63. Jaleco, A.C.; Neves, H.; Hooijberg, E.; Gameiro, P.; Clode, N.; Haury, M.; Henrique, D.; Parreira, L. Differential effects of Notch ligands Delta-1 and Jagged-1 in human lymphoid differentiation. J. Exp. Med. 2001, 194, 991-1002. [CrossRef] [PubMed]

64. Tiemessen, M.M.; Baert, M.R.; Schonewille, T.; Brugman, M.H.; Famili, F.; Salvatori, D.C.; Meijerink, J.P.; Ozbek, U.; Clevers, H.; van Dongen, J.J.; et al. The nuclear effector of Wnt-signaling, Tcf1, functions as a T-cell-specific tumor suppressor for development of lymphomas. PLoS Biol. 2012, 10, e1001430. [CrossRef]

65. Steinke, F.C.; Yu, S.; Zhou, X.; He, B.; Yang, W.; Zhou, B.; Kawamoto, H.; Zhu, J.; Tan, K.; Xue, H.H. TCF-1 and LEF-1 act upstream of Th-POK to promote the CD4(+) T cell fate and interact with Runx3 to silence Cd4 in CD8(+) T cells. Nat. Immunol. 2014, 15, 646-656. [CrossRef]

66. Vacchio, M.S.; Wang, L.; Bouladoux, N.; Carpenter, A.C.; Xiong, Y.; Williams, L.C.; Wohlfert, E.; Song, K.D.; Belkaid, Y.; Love, P.E.; et al. A ThPOK-LRF transcriptional node maintains the integrity and effector potential of post-thymic CD4 ${ }^{+}$T cells. Nat. Immunol. 2014, 15, 947-956. [CrossRef]

67. Boucheron, N.; Tschismarov, R.; Goeschl, L.; Moser, M.A.; Lagger, S.; Sakaguchi, S.; Winter, M.; Lenz, F.; Vitko, D.; Breitwieser, F.P.; et al. CD4(+) T cell lineage integrity is controlled by the histone deacetylases HDAC1 and HDAC2. Nat. Immunol. 2014, 15, 439-448. [CrossRef] 
68. Xing, S.; Li, F.; Zeng, Z.; Zhao, Y.; Yu, S.; Shan, Q.; Li, Y.; Phillips, F.C.; Maina, P.K.; Qi, H.H.; et al. Tcf1 and Lef1 transcription factors establish CD8(+) T cell identity through intrinsic HDAC activity. Nat. Immunol. 2016, 17, 695-703. [CrossRef]

69. Xu, Z.; Xing, S.; Shan, Q.; Gullicksrud, J.A.; Bair, T.B.; Du, Y.; Liu, C.; Xue, H.H. Cutting Edge: Beta-Catenin-Interacting Tcf1 Isoforms Are Essential for Thymocyte Survival but Dispensable for Thymic Maturation Transitions. J. Immunol. 2017, 198, 3404-3409. [CrossRef]

70. Yu, Q.; Xu, M.; Sen, J.M. Beta-catenin expression enhances IL-7 receptor signaling in thymocytes during positive selection. J. Immunol. 2007, 179, 126-131. [CrossRef]

71. Staal, F.J.; Meeldijk, J.; Moerer, P.; Jay, P.; van de Weerdt, B.C.; Vainio, S.; Nolan, G.P.; Clevers, H. Wnt signaling is required for thymocyte development and activates Tcf-1 mediated transcription. Eur. J. Immunol. 2001, 31, 285-293. [CrossRef]

72. Okamura, R.M.; Sigvardsson, M.; Galceran, J.; Verbeek, S.; Clevers, H.; Grosschedl, R. Redundant regulation of $\mathrm{T}$ cell differentiation and TCRalpha gene expression by the transcription factors LEF-1 and TCF-1. Immunity 1998, 8, 11-20. [CrossRef]

73. Pongracz, J.E.; Parnell, S.M.; Jones, T.; Anderson, G.; Jenkinson, E.J. Overexpression of ICAT highlights a role for catenin-mediated canonical Wnt signalling in early T cell development. Eur. J. Immunol. 2006, 36, 2376-2383. [CrossRef] [PubMed]

74. Weerkamp, F.; Baert, M.R.; Naber, B.A.; Koster, E.E.; de Haas, E.F.; Atkuri, K.R.; van Dongen, J.J.; Herzenberg, L.A.; Staal, F.J. Wnt signaling in the thymus is regulated by differential expression of intracellular signaling molecules. Proc. Natl. Acad. Sci. USA 2006, 103, 3322-3326. [CrossRef] [PubMed]

75. Lin, W.W.; Nish, S.A.; Yen, B.; Chen, Y.H.; Adams, W.C.; Kratchmarov, R.; Rothman, N.J.; Bhandoola, A.; Xue, H.H.; Reiner, S.L. CD8(+) T Lymphocyte Self-Renewal during Effector Cell Determination. Cell Rep. 2016, 17, 1773-1782. [CrossRef]

76. Gullicksrud, J.A.; Li, F.; Xing, S.; Zeng, Z.; Peng, W.; Badovinac, V.P.; Harty, J.T.; Xue, H.H. Differential Requirements for Tcf1 Long Isoforms in CD8(+) and CD4(+) T Cell Responses to Acute Viral Infection. J. Immunol. 2017, 199, 911-919. [CrossRef]

77. Yu, Q.; Sharma, A.; Oh, S.Y.; Moon, H.G.; Hossain, M.Z.; Salay, T.M.; Leeds, K.E.; Du, H.; Wu, B.; Waterman, M.L.; et al. T cell factor 1 initiates the T helper type 2 fate by inducing the transcription factor GATA-3 and repressing interferon-gamma. Nat. Immunol. 2009, 10, 992-999. [CrossRef]

78. Notani, D.; Gottimukkala, K.P.; Jayani, R.S.; Limaye, A.S.; Damle, M.V.; Mehta, S.; Purbey, P.K.; Joseph, J.; Galande, S. Global regulator SATB1 recruits beta-catenin and regulates T(H)2 differentiation in Wnt-dependent manner. PLoS Biol. 2010, 8, e1000296. [CrossRef]

79. Muranski, P.; Borman, Z.A.; Kerkar, S.P.; Klebanoff, C.A.; Ji, Y.; Sanchez-Perez, L.; Sukumar, M.; Reger, R.N.; Yu, Z.; Kern, S.J.; et al. Th17 cells are long lived and retain a stem cell-like molecular signature. Immunity 2011, 35, 972-985. [CrossRef]

80. Ghosh, M.C.; Collins, G.D.; Vandanmagsar, B.; Patel, K.; Brill, M.; Carter, A.; Lustig, A.; Becker, K.G.; Wood, W.W., 3rd; Emeche, C.D.; et al. Activation of Wnt5A signaling is required for CXC chemokine ligand 12-mediated T-cell migration. Blood 2009, 114, 1366-1373. [CrossRef]

81. Staal, F.J.; Clevers, H.C. WNT signalling and haematopoiesis: A WNT-WNT situation. Nat. Rev. Immunol. 2005, 5, 21-30. [CrossRef] [PubMed]

82. Janovska, P.; Bryja, V. Wnt signalling pathways in chronic lymphocytic leukaemia and B-cell lymphomas. Br. J. Pharmacol. 2017, 174, 4701-4715. [CrossRef] [PubMed]

83. Reya, T.; O’Riordan, M.; Okamura, R.; Devaney, E.; Willert, K.; Nusse, R.; Grosschedl, R. Wnt signaling regulates B lymphocyte proliferation through a LEF-1 dependent mechanism. Immunity 2000, 13, 15-24. [CrossRef]

84. Ranheim, E.A.; Kwan, H.C.; Reya, T.; Wang, Y.K.; Weissman, I.L.; Francke, U. Frizzled 9 knock-out mice have abnormal B-cell development. Blood 2005, 105, 2487-2494. [CrossRef] [PubMed]

85. Dosen, G.; Tenstad, E.; Nygren, M.K.; Stubberud, H.; Funderud, S.; Rian, E. Wnt expression and canonical Wnt signaling in human bone marrow B lymphopoiesis. BMC Immunol. 2006, 7, 13. [CrossRef] [PubMed]

86. Liang, H.; Chen, Q.; Coles, A.H.; Anderson, S.J.; Pihan, G.; Bradley, A.; Gerstein, R.; Jurecic, R.; Jones, S.N. Wnt5a inhibits B cell proliferation and functions as a tumor suppressor in hematopoietic tissue. Cancer Cell 2003, 4, 349-360. [CrossRef]

87. Kuppers, R.; Engert, A.; Hansmann, M.L. Hodgkin lymphoma. J. Clin. Investig. 2012, 122, 3439-3447. [CrossRef] 
88. Morrison, J.A.; Gulley, M.L.; Pathmanathan, R.; Raab-Traub, N. Differential signaling pathways are activated in the Epstein-Barr virus-associated malignancies nasopharyngeal carcinoma and Hodgkin lymphoma. Cancer Res. 2004, 64, 5251-5260. [CrossRef]

89. Sohlbach, K.; Moll, R.; Gossmann, J.; Nowak, O.; Barth, P.; Neubauer, A.; Huynh, M.Q. beta-Catenin signaling: No relevance in Hodgkin lymphoma? Leuk. Lymphoma 2012, 53, 996-998. [CrossRef]

90. Agostinelli, C.; Carloni, S.; Limarzi, F.; Righi, S.; Laginestra, M.A.; Musuraca, G.; Fiorentino, M.; Napolitano, R.; Cuneo, A.; Vergara, D.; et al. The emerging role of GSK-3beta in the pathobiology of classical Hodgkin lymphoma. Histopathology 2017, 71, 72-80. [CrossRef]

91. Tsou, P.; Katayama, H.; Ostrin, E.J.; Hanash, S.M. The Emerging Role of B Cells in Tumor Immunity. Cancer Res. 2016, 76, 5597-5601. [CrossRef] [PubMed]

92. Shen, M.; Wang, J.; Ren, X. New Insights into Tumor-Infiltrating B Lymphocytes in Breast Cancer: Clinical Impacts and Regulatory Mechanisms. Front. Immunol. 2018, 9, 470. [CrossRef] [PubMed]

93. Carmi, Y.; Spitzer, M.H.; Linde, I.L.; Burt, B.M.; Prestwood, T.R.; Perlman, N.; Davidson, M.G.; Kenkel, J.A.; Segal, E.; Pusapati, G.V.; et al. Allogeneic IgG combined with dendritic cell stimuli induce antitumour T-cell immunity. Nature 2015, 521, 99-104. [CrossRef] [PubMed]

94. Lv, Y.; Wang, H.; Liu, Z. The Role of Regulatory B Cells in Patients with Acute Myeloid Leukemia. Med. Sci. Monit. 2019, 25, 3026-3031. [CrossRef] [PubMed]

95. Wynn, T.A.; Chawla, A.; Pollard, J.W. Macrophage biology in development, homeostasis and disease. Nature 2013, 496, 445-455. [CrossRef]

96. Ovchinnikov, D.A. Macrophages in the embryo and beyond: Much more than just giant phagocytes. Genesis 2008, 46, 447-462. [CrossRef]

97. Vannella, K.M.; Wynn, T.A. Mechanisms of Organ Injury and Repair by Macrophages. Annu. Rev. Physiol. 2017, 79, 593-617. [CrossRef]

98. Schaale, K.; Neumann, J.; Schneider, D.; Ehlers, S.; Reiling, N. Wnt signaling in macrophages: Augmenting and inhibiting mycobacteria-induced inflammatory responses. Eur. J. Cell Biol. 2011, 90, 553-559. [CrossRef]

99. Villar, J.; Cabrera-Benitez, N.E.; Ramos-Nuez, A.; Flores, C.; Garcia-Hernandez, S.; Valladares, F.; Lopez-Aguilar, J.; Blanch, L.; Slutsky, A.S. Early activation of pro-fibrotic WNT5A in sepsis-induced acute lung injury. Crit. Care 2014, 18, 568. [CrossRef]

100. Zhang, P.; Katz, J.; Michalek, S.M. Glycogen synthase kinase-3beta (GSK3beta) inhibition suppresses the inflammatory response to Francisella infection and protects against tularemia in mice. Mol. Immunol. 2009, 46, 677-687. [CrossRef]

101. Palevski, D.; Levin-Kotler, L.P.; Kain, D.; Naftali-Shani, N.; Landa, N.; Ben-Mordechai, T.; Konfino, T.; Holbova, R.; Molotski, N.; Rosin-Arbesfeld, R.; et al. Loss of Macrophage Wnt Secretion Improves Remodeling and Function after Myocardial Infarction in Mice. J. Am. Heart Assoc. 2017, 6, e004387. [CrossRef] [PubMed]

102. Saha, S.; Aranda, E.; Hayakawa, Y.; Bhanja, P.; Atay, S.; Brodin, N.P.; Li, J.; Asfaha, S.; Liu, L.; Tailor, Y.; et al. Macrophage-derived extracellular vesicle-packaged WNTs rescue intestinal stem cells and enhance survival after radiation injury. Nat. Commun. 2016, 7, 13096. [CrossRef] [PubMed]

103. Cosin-Roger, J.; Ortiz-Masia, D.; Calatayud, S.; Hernandez, C.; Esplugues, J.V.; Barrachina, M.D. The activation of Wnt signaling by a STAT6-dependent macrophage phenotype promotes mucosal repair in murine IBD. Mucosal Immunol. 2016, 9, 986-998. [CrossRef] [PubMed]

104. Lin, S.L.; Li, B.; Rao, S.; Yeo, E.J.; Hudson, T.E.; Nowlin, B.T.; Pei, H.; Chen, L.; Zheng, J.J.; Carroll, T.J.; et al. Macrophage Wnt7b is critical for kidney repair and regeneration. Proc. Natl. Acad. Sci. USA 2010, 107, 4194-4199. [CrossRef] [PubMed]

105. Yeo, E.J.; Cassetta, L.; Qian, B.Z.; Lewkowich, I.; Li, J.F.; Stefater, J.A., 3rd; Smith, A.N.; Wiechmann, L.S.; Wang, Y.; Pollard, J.W.; et al. Myeloid WNT7b mediates the angiogenic switch and metastasis in breast cancer. Cancer Res. 2014, 74, 2962-2973. [CrossRef]

106. Boulter, L.; Govaere, O.; Bird, T.G.; Radulescu, S.; Ramachandran, P.; Pellicoro, A.; Ridgway, R.A.; Seo, S.S.; Spee, B.; Van Rooijen, N.; et al. Macrophage-derived Wnt opposes Notch signaling to specify hepatic progenitor cell fate in chronic liver disease. Nat. Med. 2012, 18, 572-579. [CrossRef]

107. Shao, Y.; Zheng, Q.; Wang, W.; Xin, N.; Song, X.; Zhao, C. Biological functions of macrophage-derived Wnt5a, and its roles in human diseases. Oncotarget 2016, 7, 67674-67684. [CrossRef] 
108. Pukrop, T.; Klemm, F.; Hagemann, T.; Gradl, D.; Schulz, M.; Siemes, S.; Trumper, L.; Binder, C. Wnt 5a signaling is critical for macrophage-induced invasion of breast cancer cell lines. Proc. Natl. Acad. Sci. USA 2006, 103, 5454-5459. [CrossRef]

109. Naskar, D.; Maiti, G.; Chakraborty, A.; Roy, A.; Chattopadhyay, D.; Sen, M. Wnt5a-Rac1-NF-kappaB homeostatic circuitry sustains innate immune functions in macrophages. J. Immunol. 2014, 192, 4386-4397. [CrossRef]

110. Bergenfelz, C.; Medrek, C.; Ekstrom, E.; Jirstrom, K.; Janols, H.; Wullt, M.; Bredberg, A.; Leandersson, K. Wnt5a induces a tolerogenic phenotype of macrophages in sepsis and breast cancer patients. J. Immunol. 2012, 188, 5448-5458. [CrossRef]

111. Grivennikov, S.I.; Wang, K.; Mucida, D.; Stewart, C.A.; Schnabl, B.; Jauch, D.; Taniguchi, K.; Yu, G.Y.; Osterreicher, C.H.; Hung, K.E.; et al. Adenoma-linked barrier defects and microbial products drive IL-23/IL-17-mediated tumour growth. Nature 2012, 491, 254-258. [CrossRef] [PubMed]

112. Cooks, T.; Pateras, I.S.; Jenkins, L.M.; Patel, K.M.; Robles, A.I.; Morris, J.; Forshew, T.; Appella, E.; Gorgoulis, V.G.; Harris, C.C. Mutant p53 cancers reprogram macrophages to tumor supporting macrophages via exosomal miR-1246. Nat. Commun. 2018, 9, 771. [CrossRef] [PubMed]

113. Pillay, J.; den Braber, I.; Vrisekoop, N.; Kwast, L.M.; de Boer, R.J.; Borghans, J.A.; Tesselaar, K.; Koenderman, L. In vivo labeling with ${ }^{2} \mathrm{H}_{2} \mathrm{O}$ reveals a human neutrophil lifespan of 5.4 days. Blood 2010, 116, 625-627. [CrossRef] [PubMed]

114. Park, Y.M.; Bochner, B.S. Eosinophil survival and apoptosis in health and disease. Allergy Asthma Immunol. Res. 2010, 2, 87-101. [CrossRef]

115. Jung, Y.S.; Lee, H.Y.; Kim, S.D.; Park, J.S.; Kim, J.K.; Suh, P.G.; Bae, Y.S. Wnt5a stimulates chemotactic migration and chemokine production in human neutrophils. Exp. Mol. Med. 2013, 45, e27. [CrossRef]

116. Januskevicius, A.; Vaitkiene, S.; Gosens, R.; Janulaityte, I.; Hoppenot, D.; Sakalauskas, R.; Malakauskas, K. Eosinophils enhance WNT-5a and TGF-beta1 genes expression in airway smooth muscle cells and promote their proliferation by increased extracellular matrix proteins production in asthma. BMC Pulm. Med. 2016, 16, 94. [CrossRef]

117. Rodewald, H.R.; Feyerabend, T.B. Widespread immunological functions of mast cells: Fact or fiction? Immunity 2012, 37, 13-24. [CrossRef]

118. Gurish, M.F.; Austen, K.F. Developmental origin and functional specialization of mast cell subsets. Immunity 2012, 37, 25-33. [CrossRef]

119. Yamaguchi, T.; Nishijima, M.; Tashiro, K.; Kawabata, K. Wnt-beta-Catenin Signaling Promotes the Maturation of Mast Cells. BioMed Res. Int. 2016, 2016, 2048987. [CrossRef]

120. Dyduch, G.; Kaczmarczyk, K.; Okon, K. Mast cells and cancer: Enemies or allies? Pol. J. Pathol. 2012, 63, 1-7.

121. Lin, S.Y.; Xia, W.; Wang, J.C.; Kwong, K.Y.; Spohn, B.; Wen, Y.; Pestell, R.G.; Hung, M.C. Beta-catenin, a novel prognostic marker for breast cancer: Its roles in cyclin D1 expression and cancer progression. Proc. Natl. Acad. Sci. USA 2000, 97, 4262-4266. [CrossRef] [PubMed]

122. Geyer, F.C.; Lacroix-Triki, M.; Savage, K.; Arnedos, M.; Lambros, M.B.; MacKay, A.; Natrajan, R.; Reis-Filho, J.S. beta-Catenin pathway activation in breast cancer is associated with triple-negative phenotype but not with CTNNB1 mutation. Mod. Pathol. 2011, 24, 209-231. [CrossRef] [PubMed]

123. Khramtsov, A.I.; Khramtsova, G.F.; Tretiakova, M.; Huo, D.; Olopade, O.I.; Goss, K.H. Wnt/beta-catenin pathway activation is enriched in basal-like breast cancers and predicts poor outcome. Am. J. Pathol. 2010, 176, 2911-2920. [CrossRef] [PubMed]

124. Li, S.; Li, S.; Sun, Y.; Li, L. The expression of beta-catenin in different subtypes of breast cancer and its clinical significance. Tumour Biol. 2014, 35, 7693-7698. [CrossRef] [PubMed]

125. Chakrabarti, R.; Wei, Y.; Hwang, J.; Hang, X.; Andres Blanco, M.; Choudhury, A.; Tiede, B.; Romano, R.A.; DeCoste, C.; Mercatali, L.; et al. DeltaNp63 promotes stem cell activity in mammary gland development and basal-like breast cancer by enhancing Fzd7 expression and Wnt signalling. Nat. Cell Biol. 2014, 16, 1004-1015. [CrossRef]

126. Klauzinska, M.; Baljinnyam, B.; Raafat, A.; Rodriguez-Canales, J.; Strizzi, L.; Greer, Y.E.; Rubin, J.S.; Callahan, R. Rspo2/Int7 regulates invasiveness and tumorigenic properties of mammary epithelial cells. J. Cell. Physiol. 2012, 227, 1960-1971. [CrossRef]

127. Cui, B.; Zhang, S.; Chen, L.; Yu, J.; Widhopf, G.F., 2nd; Fecteau, J.F.; Rassenti, L.Z.; Kipps, T.J. Targeting ROR1 inhibits epithelial-mesenchymal transition and metastasis. Cancer Res. 2013, 73, 3649-3660. [CrossRef] 
128. Castagnoli, L.; Cancila, V.; Cordoba-Romero, S.L.; Faraci, S.; Talarico, G.; Belmonte, B.; Iorio, M.V.; Milani, M.; Volpari, T.; Chiodoni, C.; et al. WNT signaling modulates PD-L1 expression in the stem cell compartment of triple-negative breast cancer. Oncogene 2019, 38, 4047-4060. [CrossRef]

129. Xu, Z.; Robitaille, A.M.; Berndt, J.D.; Davidson, K.C.; Fischer, K.A.; Mathieu, J.; Potter, J.C.; Ruohola-Baker, H.; Moon, R.T. Wnt/beta-catenin signaling promotes self-renewal and inhibits the primed state transition in naive human embryonic stem cells. Proc. Natl. Acad. Sci. USA 2016, 113, E6382-E6390. [CrossRef]

130. Merino, V.F.; Cho, S.; Liang, X.; Park, S.; Jin, K.; Chen, Q.; Pan, D.; Zahnow, C.A.; Rein, A.R.; Sukumar, S. Inhibitors of STAT3, beta-catenin, and IGF-1R sensitize mouse PIK3CA-mutant breast cancer to PI3K inhibitors. Mol. Oncol. 2017, 11, 552-566. [CrossRef]

131. Chiang, K.C.; Yeh, C.N.; Chung, L.C.; Feng, T.H.; Sun, C.C.; Chen, M.F.; Jan, Y.Y.; Yeh, T.S.; Chen, S.C.; Juang, H.H. WNT-1 inducible signaling pathway protein-1 enhances growth and tumorigenesis in human breast cancer. Sci. Rep. 2015, 5, 8686. [CrossRef] [PubMed]

132. Cleary, A.S.; Leonard, T.L.; Gestl, S.A.; Gunther, E.J. Tumour cell heterogeneity maintained by cooperating subclones in Wnt-driven mammary cancers. Nature 2014, 508, 113-117. [CrossRef] [PubMed]

133. Lindvall, C.; Evans, N.C.; Zylstra, C.R.; Li, Y.; Alexander, C.M.; Williams, B.O. The Wnt signaling receptor Lrp5 is required for mammary ductal stem cell activity and Wnt1-induced tumorigenesis. J. Biol. Chem. 2006, 281, 35081-35087. [CrossRef] [PubMed]

134. Lv, C.; Li, F.; Li, X.; Tian, Y.; Zhang, Y.; Sheng, X.; Song, Y.; Meng, Q.; Yuan, S.; Luan, L.; et al. MiR-31 promotes mammary stem cell expansion and breast tumorigenesis by suppressing Wnt signaling antagonists. Nat. Commun. 2017, 8, 1036. [CrossRef]

135. Liu, S.; Cong, Y.; Wang, D.; Sun, Y.; Deng, L.; Liu, Y.; Martin-Trevino, R.; Shang, L.; McDermott, S.P.; Landis, M.D.; et al. Breast cancer stem cells transition between epithelial and mesenchymal states reflective of their normal counterparts. Stem Cell Rep. 2014, 2, 78-91. [CrossRef]

136. Lim, S.K.; Lu, S.Y.; Kang, S.A.; Tan, H.J.; Li, Z.; Adrian Wee, Z.N.; Guan, J.S.; Reddy Chichili, V.P.; Sivaraman, J.; Putti, T.; et al. Wnt Signaling Promotes Breast Cancer by Blocking ITCH-Mediated Degradation of YAP/TAZ Transcriptional Coactivator WBP2. Cancer Res. 2016, 76, 6278-6289. [CrossRef]

137. Luis, T.C.; Ichii, M.; Brugman, M.H.; Kincade, P.; Staal, F.J. Wnt signaling strength regulates normal hematopoiesis and its deregulation is involved in leukemia development. Leukemia 2012, 26, 414-421. [CrossRef]

138. Kamran, S.; Awan, S.A.; Ahmad, K.N.; Iqbal, Y. Acute Myeloid Leukemia with t(8;21)(q22;q22) and Trisomy 4: A Rare Occurrence in a Female Child. Cureus 2019, 11, e3885. [CrossRef]

139. Sakoda, T.; Kikushige, Y.; Miyamoto, T.; Akashi, K. Canonical Wnt Pathway Is Activated in Myeloid Leukemia Stem Cells Via Hematopoietic Cell Kinase That Is Phosphorylated By an Autocrine TIM-3/Galectin-9 Signaling; The American Society of Hematology: Washington, DC, USA, 2017.

140. Hong, C.S.; Muller, L.; Whiteside, T.L.; Boyiadzis, M. Plasma exosomes as markers of therapeutic response in patients with acute myeloid leukemia. Front. Immunol. 2014, 5, 160. [CrossRef]

141. Yeung, J.; Esposito, M.T.; Gandillet, A.; Zeisig, B.B.; Griessinger, E.; Bonnet, D.; So, C.W. beta-Catenin mediates the establishment and drug resistance of MLL leukemic stem cells. Cancer Cell 2010, 18, 606-618. [CrossRef]

142. Lane, S.W.; Wang, Y.J.; Lo Celso, C.; Ragu, C.; Bullinger, L.; Sykes, S.M.; Ferraro, F.; Shterental, S.; Lin, C.P.; Gilliland, D.G.; et al. Differential niche and Wnt requirements during acute myeloid leukemia progression. Blood 2011, 118, 2849-2856. [CrossRef] [PubMed]

143. Wang, Y.; Krivtsov, A.V.; Sinha, A.U.; North, T.E.; Goessling, W.; Feng, Z.; Zon, L.I.; Armstrong, S.A. The Wnt/beta-catenin pathway is required for the development of leukemia stem cells in AML. Science 2010, 327, 1650-1653. [CrossRef] [PubMed]

144. Cheng, C.K.; Li, L.; Cheng, S.H.; Lau, K.M.; Chan, N.P.; Wong, R.S.; Shing, M.M.; Li, C.K.; Ng, M.H. Transcriptional repression of the RUNX3/AML2 gene by the $t(8 ; 21)$ and inv(16) fusion proteins in acute myeloid leukemia. Blood 2008, 112, 3391-3402. [CrossRef] [PubMed]

145. Muller-Tidow, C.; Steffen, B.; Cauvet, T.; Tickenbrock, L.; Ji, P.; Diederichs, S.; Sargin, B.; Kohler, G.; Stelljes, M.; Puccetti, E.; et al. Translocation products in acute myeloid leukemia activate the Wnt signaling pathway in hematopoietic cells. Mol. Cell. Biol. 2004, 24, 2890-2904. [CrossRef] [PubMed] 
146. Kode, A.; Mosialou, I.; Manavalan, S.J.; Rathinam, C.V.; Friedman, R.A.; Teruya-Feldstein, J.; Bhagat, G.; Berman, E.; Kousteni, S. FoxO1-dependent induction of acute myeloid leukemia by osteoblasts in mice. Leukemia 2016, 30, 1-13. [CrossRef]

147. Ferrando, A.A. The role of NOTCH1 signaling in T-ALL. Hematol. Am. Soc. Hematol. Educ. Program 2009, 2009, 353-361. [CrossRef]

148. Kaveri, D.; Kastner, P.; Dembele, D.; Nerlov, C.; Chan, S.; Kirstetter, P. beta-Catenin activation synergizes with Pten loss and Myc overexpression in Notch-independent T-ALL. Blood 2013, 122, 694-704. [CrossRef]

149. Guo, W.; Lasky, J.L.; Chang, C.J.; Mosessian, S.; Lewis, X.; Xiao, Y.; Yeh, J.E.; Chen, J.Y.; Iruela-Arispe, M.L.; Varella-Garcia, M.; et al. Multi-genetic events collaboratively contribute to Pten-null leukaemia stem-cell formation. Nature 2008, 453, 529-533. [CrossRef]

150. Giambra, V.; Jenkins, C.E.; Lam, S.H.; Hoofd, C.; Belmonte, M.; Wang, X.; Gusscott, S.; Gracias, D.; Weng, A.P. Leukemia stem cells in T-ALL require active Hif1alpha and Wnt signaling. Blood 2015, 125, 3917-3927. [CrossRef]

151. Kipps, T.J.; Stevenson, F.K.; Wu, C.J.; Croce, C.M.; Packham, G.; Wierda, W.G.; O’Brien, S.; Gribben, J.; Rai, K. Chronic lymphocytic leukaemia. Nat. Rev. Dis. Primers 2017, 3, 16096. [CrossRef]

152. Lu, D.; Zhao, Y.; Tawatao, R.; Cottam, H.B.; Sen, M.; Leoni, L.M.; Kipps, T.J.; Corr, M.; Carson, D.A. Activation of the Wnt signaling pathway in chronic lymphocytic leukemia. Proc. Natl. Acad. Sci. USA 2004, 101, 3118-3123. [CrossRef] [PubMed]

153. Moskalev, E.A.; Luckert, K.; Vorobjev, I.A.; Mastitsky, S.E.; Gladkikh, A.A.; Stephan, A.; Schrenk, M.; Kaplanov, K.D.; Kalashnikova, O.B.; Potz, O.; et al. Concurrent epigenetic silencing of wnt/beta-catenin pathway inhibitor genes in B cell chronic lymphocytic leukaemia. BMC Cancer 2012, 12, 213. [CrossRef] [PubMed]

154. Wang, L.; Shalek, A.K.; Lawrence, M.; Ding, R.; Gaublomme, J.T.; Pochet, N.; Stojanov, P.; Sougnez, C.; Shukla, S.A.; Stevenson, K.E.; et al. Somatic mutation as a mechanism of Wnt/beta-catenin pathway activation in CLL. Blood 2014, 124, 1089-1098. [CrossRef] [PubMed]

155. Fukuda, T.; Chen, L.; Endo, T.; Tang, L.; Lu, D.; Castro, J.E.; Widhopf, G.F., 2nd; Rassenti, L.Z.; Cantwell, M.J.; Prussak, C.E.; et al. Antisera induced by infusions of autologous Ad-CD154-leukemia B cells identify ROR1 as an oncofetal antigen and receptor for Wnt5a. Proc. Natl. Acad. Sci. USA 2008, 105, 3047-3052. [CrossRef]

156. Howe, D.; Bromidge, T. Variation of LEF-1 mRNA expression in low-grade B-cell non-Hodgkin's lymphoma. Leuk. Res. 2006, 30, 29-32. [CrossRef]

157. Haderk, F.; Schulz, R.; Iskar, M.; Cid, L.L.; Worst, T.; Willmund, K.V.; Schulz, A.; Warnken, U.; Seiler, J.; Benner, A.; et al. Tumor-derived exosomes modulate PD-L1 expression in monocytes. Sci. Immunol. 2017, 2. [CrossRef]

158. Ren, Z.; van Andel, H.; de Lau, W.; Hartholt, R.B.; Maurice, M.M.; Clevers, H.; Kersten, M.J.; Spaargaren, M.; Pals, S.T. Syndecan-1 promotes Wnt/beta-catenin signaling in multiple myeloma by presenting Wnts and R-spondins. Blood 2018, 131, 982-994. [CrossRef]

159. Haseeb, M.; Anwar, M.A.; Choi, S. Molecular Interactions between Innate and Adaptive Immune Cells in Chronic Lymphocytic Leukemia and Their Therapeutic Implications. Front. Immunol. 2018, 9, 2720. [CrossRef]

160. Chiurillo, M.A. Role of the Wnt/beta-catenin pathway in gastric cancer: An in-depth literature review. World J. Exp. Med. 2015, 5, 84-102. [CrossRef]

161. Seshagiri, S.; Stawiski, E.W.; Durinck, S.; Modrusan, Z.; Storm, E.E.; Conboy, C.B.; Chaudhuri, S.; Guan, Y.; Janakiraman, V.; Jaiswal, B.S.; et al. Recurrent R-spondin fusions in colon cancer. Nature 2012, 488, 660-664. [CrossRef]

162. Cancer Genome Atlas Network. Comprehensive molecular characterization of human colon and rectal cancer. Nature 2012, 487, 330-337. [CrossRef] [PubMed]

163. Bass, A.J.; Lawrence, M.S.; Brace, L.E.; Ramos, A.H.; Drier, Y.; Cibulskis, K.; Sougnez, C.; Voet, D.; Saksena, G.; Sivachenko, A.; et al. Genomic sequencing of colorectal adenocarcinomas identifies a recurrent VTI1A-TCF7L2 fusion. Nat. Genet. 2011, 43, 964-968. [CrossRef] [PubMed]

164. Sanz-Pamplona, R.; Lopez-Doriga, A.; Pare-Brunet, L.; Lazaro, K.; Bellido, F.; Alonso, M.H.; Ausso, S.; Guino, E.; Beltran, S.; Castro-Giner, F.; et al. Exome Sequencing Reveals AMER1 as a Frequently Mutated Gene in Colorectal Cancer. Clin. Cancer Res. 2015, 21, 4709-4718. [CrossRef] [PubMed] 
165. Wang, W.; Pan, Q.; Fuhler, G.M.; Smits, R.; Peppelenbosch, M.P. Action and function of Wnt/beta-catenin signaling in the progression from chronic hepatitis C to hepatocellular carcinoma. J. Gastroenterol. 2017, 52, 419-431. [CrossRef]

166. Matano, M.; Date, S.; Shimokawa, M.; Takano, A.; Fujii, M.; Ohta, Y.; Watanabe, T.; Kanai, T.; Sato, T. Modeling colorectal cancer using CRISPR-Cas9-mediated engineering of human intestinal organoids. Nat. Med. 2015, 21, 256-262. [CrossRef]

167. Drost, J.; van Jaarsveld, R.H.; Ponsioen, B.; Zimberlin, C.; van Boxtel, R.; Buijs, A.; Sachs, N.; Overmeer, R.M.; Offerhaus, G.J.; Begthel, H.; et al. Sequential cancer mutations in cultured human intestinal stem cells. Nature 2015, 521, 43-47. [CrossRef]

168. Christie, M.; Jorissen, R.N.; Mouradov, D.; Sakthianandeswaren, A.; Li, S.; Day, F.; Tsui, C.; Lipton, L.; Desai, J.; Jones, I.T.; et al. Different APC genotypes in proximal and distal sporadic colorectal cancers suggest distinct WNT/beta-catenin signalling thresholds for tumourigenesis. Oncogene 2013, 32, 4675-4682. [CrossRef]

169. Buchert, M.; Athineos, D.; Abud, H.E.; Burke, Z.D.; Faux, M.C.; Samuel, M.S.; Jarnicki, A.G.; Winbanks, C.E.; Newton, I.P.; Meniel, V.S.; et al. Genetic dissection of differential signaling threshold requirements for the Wnt/beta-catenin pathway in vivo. PLoS Genet. 2010, 6, e1000816. [CrossRef]

170. Dow, L.E.; O’Rourke, K.P.; Simon, J.; Tschaharganeh, D.F.; van Es, J.H.; Clevers, H.; Lowe, S.W. Apc Restoration Promotes Cellular Differentiation and Reestablishes Crypt Homeostasis in Colorectal Cancer. Cell 2015, 161, 1539-1552. [CrossRef]

171. Takano, Y.; Masuda, T.; Iinuma, H.; Yamaguchi, R.; Sato, K.; Tobo, T.; Hirata, H.; Kuroda, Y.; Nambara, S.; Hayashi, N.; et al. Circulating exosomal microRNA-203 is associated with metastasis possibly via inducing tumor-associated macrophages in colorectal cancer. Oncotarget 2017, 8, 78598-78613. [CrossRef]

172. Yong, X.; Tang, B.; Xiao, Y.F.; Xie, R.; Qin, Y.; Luo, G.; Hu, C.J.; Dong, H.; Yang, S.M. Helicobacter pylori upregulates Nanog and Oct4 via Wnt/beta-catenin signaling pathway to promote cancer stem cell-like properties in human gastric cancer. Cancer Lett. 2016, 374, 292-303. [CrossRef] [PubMed]

173. Santos, J.C.; Carrasco-Garcia, E.; Garcia-Puga, M.; Aldaz, P.; Montes, M.; Fernandez-Reyes, M.; de Oliveira, C.C.; Lawrie, C.H.; Arauzo-Bravo, M.J.; Ribeiro, M.L.; et al. SOX9 Elevation Acts with Canonical WNT Signaling to Drive Gastric Cancer Progression. Cancer Res. 2016, 76, 6735-6746. [CrossRef] [PubMed]

174. Peng, Q.; Chen, L.; Wu, W.; Wang, J.; Zheng, X.; Chen, Z.; Jiang, Q.; Han, J.; Wei, L.; Wang, L.; et al. EPH receptor A2 governs a feedback loop that activates Wnt/beta-catenin signaling in gastric cancer. Cell Death Dis. 2018, 9, 1146. [CrossRef]

175. Ara, H.; Takagishi, M.; Enomoto, A.; Asai, M.; Ushida, K.; Asai, N.; Shimoyama, Y.; Kaibuchi, K.; Kodera, Y.; Takahashi, M. Role for Daple in non-canonical Wnt signaling during gastric cancer invasion and metastasis. Cancer Sci. 2016, 107, 133-139. [CrossRef] [PubMed]

176. Van de Wetering, M.; Francies, H.E.; Francis, J.M.; Bounova, G.; Iorio, F.; Pronk, A.; van Houdt, W.; van Gorp, J.; Taylor-Weiner, A.; Kester, L.; et al. Prospective derivation of a living organoid biobank of colorectal cancer patients. Cell 2015, 161, 933-945. [CrossRef] [PubMed]

177. Shi, Y.; Bai, J.; Guo, S.; Wang, J. Wntless Is Highly Expressed in Advanced-Stage Intrahepatic Cholangiocarcinoma. Tohoku J. Exp. Med. 2018, 244, 195-199. [CrossRef]

178. Goeppert, B.; Konermann, C.; Schmidt, C.R.; Bogatyrova, O.; Geiselhart, L.; Ernst, C.; Gu, L.; Becker, N.; Zucknick, M.; Mehrabi, A.; et al. Global alterations of DNA methylation in cholangiocarcinoma target the Wnt signaling pathway. Hepatology 2014, 59, 544-554. [CrossRef]

179. Zheng, Y.; Zhou, C.; Yu, X.X.; Wu, C.; Jia, H.L.; Gao, X.M.; Yang, J.M.; Wang, C.Q.; Luo, Q.; Zhu, Y.; et al. Osteopontin promotes metastasis of intrahepatic cholangiocarcinoma through recruiting MAPK1 and mediating Ser675 phosphorylation of beta-Catenin. Cell Death Dis. 2018, 9, 179. [CrossRef]

180. Boulter, L.; Guest, R.V.; Kendall, T.J.; Wilson, D.H.; Wojtacha, D.; Robson, A.J.; Ridgway, R.A.; Samuel, K.; Van Rooijen, N.; Barry, S.T.; et al. WNT signaling drives cholangiocarcinoma growth and can be pharmacologically inhibited. J. Clin. Investig. 2015, 125, 1269-1285. [CrossRef]

181. Loilome, W.; Bungkanjana, P.; Techasen, A.; Namwat, N.; Yongvanit, P.; Puapairoj, A.; Khuntikeo, N.; Riggins, G.J. Activated macrophages promote Wnt/beta-catenin signaling in cholangiocarcinoma cells. Tumor Biol. 2014, 35, 5357-5367. [CrossRef]

182. Chan-On, W.; Nairismagi, M.L.; Ong, C.K.; Lim, W.K.; Dima, S.; Pairojkul, C.; Lim, K.H.; McPherson, J.R.; Cutcutache, I.; Heng, H.L.; et al. Exome sequencing identifies distinct mutational patterns in liver fluke-related and non-infection-related bile duct cancers. Nat. Genet. 2013, 45, 1474-1478. [CrossRef] [PubMed] 
183. Oliveira, L.A.; Oshima, C.T.F.; Soffner, P.A.; Silva, M.S.; Lins, R.R.; Malinverni, A.C.M.; Waisberg, J. The Canonical Wnt Pathway in Gastric Carcinoma. Arq. Bras. Cir. Dig. 2019, 32, e1414. [CrossRef] [PubMed]

184. Noelanders, R.; Vleminckx, K. How Wnt Signaling Builds the Brain: Bridging Development and Disease. Neuroscientist 2017, 23, 314-329. [CrossRef] [PubMed]

185. Takahashi, H.; Liu, F.C. Genetic patterning of the mammalian telencephalon by morphogenetic molecules and transcription factors. Birth Defects Res. C Embryo Today 2006, 78, 256-266. [CrossRef] [PubMed]

186. Kalani, M.Y.; Cheshier, S.H.; Cord, B.J.; Bababeygy, S.R.; Vogel, H.; Weissman, I.L.; Palmer, T.D.; Nusse, R. Wnt-mediated self-renewal of neural stem/progenitor cells. Proc. Natl. Acad. Sci. USA 2008, 105, 16970-16975. [CrossRef]

187. Chenn, A.; Walsh, C.A. Regulation of cerebral cortical size by control of cell cycle exit in neural precursors. Science 2002, 297, 365-369. [CrossRef]

188. Zechner, D.; Fujita, Y.; Hulsken, J.; Muller, T.; Walther, I.; Taketo, M.M.; Crenshaw, E.B., 3rd; Birchmeier, W.; Birchmeier, $\mathrm{C}$. beta-Catenin signals regulate cell growth and the balance between progenitor cell expansion and differentiation in the nervous system. Dev. Biol. 2003, 258, 406-418. [CrossRef]

189. Birchmeier, C.; Birchmeier, W.; Gherardi, E.; Vande Woude, G.F. Met, metastasis, motility and more. Nat. Rev. Mol. Cell Biol. 2003, 4, 915-925. [CrossRef]

190. Kong, D.S.; Song, S.Y.; Kim, D.H.; Joo, K.M.; Yoo, J.S.; Koh, J.S.; Dong, S.M.; Suh, Y.L.; Lee, J.I.; Park, K.; et al. Prognostic significance of c-Met expression in glioblastomas. Cancer 2009, 115, 140-148. [CrossRef]

191. Kim, K.H.; Seol, H.J.; Kim, E.H.; Rheey, J.; Jin, H.J.; Lee, Y.; Joo, K.M.; Lee, J.; Nam, D.H. Wnt/beta-catenin signaling is a key downstream mediator of MET signaling in glioblastoma stem cells. Neuro Oncol. 2013, 15, 161-171. [CrossRef]

192. Morris, L.G.; Kaufman, A.M.; Gong, Y.; Ramaswami, D.; Walsh, L.A.; Turcan, S.; Eng, S.; Kannan, K.; Zou, Y.; Peng, L.; et al. Recurrent somatic mutation of FAT1 in multiple human cancers leads to aberrant Wnt activation. Nat. Genet. 2013, 45, 253-261. [CrossRef] [PubMed]

193. Roth, W.; Wild-Bode, C.; Platten, M.; Grimmel, C.; Melkonyan, H.S.; Dichgans, J.; Weller, M. Secreted Frizzled-related proteins inhibit motility and promote growth of human malignant glioma cells. Oncogene 2000, 19, 4210-4220. [CrossRef] [PubMed]

194. Schiefer, L.; Visweswaran, M.; Perumal, V.; Arfuso, F.; Groth, D.; Newsholme, P.; Warrier, S.; Dharmarajan, A. Epigenetic regulation of the secreted frizzled-related protein family in human glioblastoma multiforme. Cancer Gene Ther. 2014, 21, 297-303. [CrossRef] [PubMed]

195. Foltz, G.; Yoon, J.G.; Lee, H.; Ma, L.; Tian, Q.; Hood, L.; Madan, A. Epigenetic regulation of wnt pathway antagonists in human glioblastoma multiforme. Genes Cancer 2010, 1, 81-90. [CrossRef] [PubMed]

196. Zheng, H.; Ying, H.; Wiedemeyer, R.; Yan, H.; Quayle, S.N.; Ivanova, E.V.; Paik, J.H.; Zhang, H.; Xiao, Y.; Perry, S.R.; et al. PLAGL2 regulates Wnt signaling to impede differentiation in neural stem cells and gliomas. Cancer Cell 2010, 17, 497-509. [CrossRef]

197. Moon, R.T.; Kohn, A.D.; De Ferrari, G.V.; Kaykas, A. WNT and beta-catenin signalling: Diseases and therapies. Nat. Rev. Genet. 2004, 5, 691-701. [CrossRef]

198. Najdi, R.; Holcombe, R.F.; Waterman, M.L. Wnt signaling and colon carcinogenesis: Beyond APC. J. Carcinog. 2011, 10, 5. [CrossRef]

199. Gurney, A.; Axelrod, F.; Bond, C.J.; Cain, J.; Chartier, C.; Donigan, L.; Fischer, M.; Chaudhari, A.; Ji, M.; Kapoun, A.M.; et al. Wnt pathway inhibition via the targeting of Frizzled receptors results in decreased growth and tumorigenicity of human tumors. Proc. Natl. Acad. Sci. USA 2012, 109, 11717-11722. [CrossRef]

200. Steinhart, Z.; Pavlovic, Z.; Chandrashekhar, M.; Hart, T.; Wang, X.; Zhang, X.; Robitaille, M.; Brown, K.R.; Jaksani, S.; Overmeer, R.; et al. Genome-wide CRISPR screens reveal a Wnt-FZD5 signaling circuit as a druggable vulnerability of RNF43-mutant pancreatic tumors. Nat. Med. 2017, 23, 60-68. [CrossRef]

201. Nielsen, T.O.; Poulin, N.M.; Ladanyi, M. Synovial sarcoma: Recent discoveries as a roadmap to new avenues for therapy. Cancer Discov. 2015, 5, 124-134. [CrossRef]

202. Gong, X.; Azhdarinia, A.; Ghosh, S.C.; Xiong, W.; An, Z.; Liu, Q.; Carmon, K.S. LGR5-Targeted Antibody-Drug Conjugate Eradicates Gastrointestinal Tumors and Prevents Recurrence. Mol. Cancer Ther. 2016, 15, 1580-1590. [CrossRef] [PubMed]

203. Zhang, S.; Cui, B.; Lai, H.; Liu, G.; Ghia, E.M.; Widhopf, G.F., 2nd; Zhang, Z.; Wu, C.C.; Chen, L.; Wu, R.; et al. Ovarian cancer stem cells express ROR1, which can be targeted for anti-cancer-stem-cell therapy. Proc. Natl. Acad. Sci. USA 2014, 111, 17266-17271. [CrossRef] [PubMed] 
204. Damelin, M.; Bankovich, A.; Bernstein, J.; Lucas, J.; Chen, L.; Williams, S.; Park, A.; Aguilar, J.; Ernstoff, E.; Charati, M.; et al. A PTK7-targeted antibody-drug conjugate reduces tumor-initiating cells and induces sustained tumor regressions. Sci. Transl. Med. 2017, 9. [CrossRef] [PubMed]

205. Storm, E.E.; Durinck, S.; de Sousa e Melo, F.; Tremayne, J.; Kljavin, N.; Tan, C.; Ye, X.; Chiu, C.; Pham, T.; Hongo, J.A.; et al. Targeting PTPRK-RSPO3 colon tumours promotes differentiation and loss of stem-cell function. Nature 2016, 529, 97-100. [CrossRef] [PubMed]

206. Appelman-Dijkstra, N.M.; Papapoulos, S.E. Sclerostin Inhibition in the Management of Osteoporosis. Calcif. Tissue Int. 2016, 98, 370-380. [CrossRef] [PubMed]

207. Le, P.N.; McDermott, J.D.; Jimeno, A. Targeting the Wnt pathway in human cancers: Therapeutic targeting with a focus on OMP-54F28. Pharmacol. Ther. 2015, 146, 1-11. [CrossRef]

208. Berger, C.; Sommermeyer, D.; Hudecek, M.; Berger, M.; Balakrishnan, A.; Paszkiewicz, P.J.; Kosasih, P.L.; Rader, C.; Riddell, S.R. Safety of targeting ROR1 in primates with chimeric antigen receptor-modified T cells. Cancer Immunol. Res. 2015, 3, 206-216. [CrossRef]

209. Poulsen, A.; Ho, S.Y.; Wang, W.; Alam, J.; Jeyaraj, D.A.; Ang, S.H.; Tan, E.S.; Lin, G.R.; Cheong, V.W.; Ke, Z.; et al. Pharmacophore Model for Wnt/Porcupine Inhibitors and Its Use in Drug Design. J. Chem. Inf. Model. 2015, 55, 1435-1448. [CrossRef]

210. Langton, P.F.; Kakugawa, S.; Vincent, J.P. Making, Exporting, and Modulating Wnts. Trends Cell Biol. 2016, 26, 756-765. [CrossRef]

211. Agarwal, P.; Zhang, B.; Ho, Y.; Cook, A.; Li, L.; Mikhail, F.M.; Wang, Y.; McLaughlin, M.E.; Bhatia, R. Enhanced targeting of CML stem and progenitor cells by inhibition of porcupine acyltransferase in combination with TKI. Blood 2017, 129, 1008-1020. [CrossRef]

212. Chen, B.; Dodge, M.E.; Tang, W.; Lu, J.; Ma, Z.; Fan, C.W.; Wei, S.; Hao, W.; Kilgore, J.; Williams, N.S.; et al. Small molecule-mediated disruption of Wnt-dependent signaling in tissue regeneration and cancer. Nat. Chem. Biol. 2009, 5, 100-107. [CrossRef] [PubMed]

213. Proffitt, K.D.; Madan, B.; Ke, Z.; Pendharkar, V.; Ding, L.; Lee, M.A.; Hannoush, R.N.; Virshup, D.M. Pharmacological inhibition of the Wnt acyltransferase PORCN prevents growth of WNT-driven mammary cancer. Cancer Res. 2013, 73, 502-507. [CrossRef] [PubMed]

214. Bhamra, I.; Armer, R.; Bingham, M.; Eagle, C.; Cook, A.E.; Phillips, C.; Woodcock, S. Abstract 3764: Porcupine inhibitor RXC004 enhances immune response in pre-clinical models of cancer. Cancer Res. 2018, 78, 3764. [CrossRef]

215. Madan, B.; Ke, Z.; Harmston, N.; Ho, S.Y.; Frois, A.O.; Alam, J.; Jeyaraj, D.A.; Pendharkar, V.; Ghosh, K.; Virshup, I.H.; et al. Wnt addiction of genetically defined cancers reversed by PORCN inhibition. Oncogene 2016, 35, 2197-2207. [CrossRef] [PubMed]

216. Tammela, T.; Sanchez-Rivera, F.J.; Cetinbas, N.M.; Wu, K.; Joshi, N.S.; Helenius, K.; Park, Y.; Azimi, R.; Kerper, N.R.; Wesselhoeft, R.A.; et al. A Wnt-producing niche drives proliferative potential and progression in lung adenocarcinoma. Nature 2017, 545, 355-359. [CrossRef] [PubMed]

217. Valenta, T.; Degirmenci, B.; Moor, A.E.; Herr, P.; Zimmerli, D.; Moor, M.B.; Hausmann, G.; Cantu, C.; Aguet, M.; Basler, K. Wnt Ligands Secreted by Subepithelial Mesenchymal Cells Are Essential for the Survival of Intestinal Stem Cells and Gut Homeostasis. Cell Rep. 2016, 15, 911-918. [CrossRef] [PubMed]

218. Yuzugullu, H.; Benhaj, K.; Ozturk, N.; Senturk, S.; Celik, E.; Toylu, A.; Tasdemir, N.; Yilmaz, M.; Erdal, E.; Akcali, K.C.; et al. Canonical Wnt signaling is antagonized by noncanonical Wnt5a in hepatocellular carcinoma cells. Mol. Cancer 2009, 8, 90. [CrossRef] [PubMed]

219. Boone, J.D.; Arend, R.C.; Johnston, B.E.; Cooper, S.J.; Gilchrist, S.A.; Oelschlager, D.K.; Grizzle, W.E.; McGwin, G., Jr.; Gangrade, A.; Straughn, J.M., Jr.; et al. Targeting the Wnt/beta-catenin pathway in primary ovarian cancer with the porcupine inhibitor WNT974. Lab. Investig. 2016, 96, 249-259. [CrossRef]

220. Liu, J.; Pan, S.; Hsieh, M.H.; Ng, N.; Sun, F.; Wang, T.; Kasibhatla, S.; Schuller, A.G.; Li, A.G.; Cheng, D.; et al. Targeting Wnt-driven cancer through the inhibition of Porcupine by LGK974. Proc. Natl. Acad. Sci. USA 2013, 110, 20224-20229. [CrossRef]

221. Solzak, J.P.; Atale, R.V.; Hancock, B.A.; Sinn, A.L.; Pollok, K.E.; Jones, D.R.; Radovich, M. Dual PI3K and Wnt pathway inhibition is a synergistic combination against triple negative breast cancer. NPJ Breast Cancer 2017, 3, 17. [CrossRef] 
222. Jiang, X.; Hao, H.X.; Growney, J.D.; Woolfenden, S.; Bottiglio, C.; Ng, N.; Lu, B.; Hsieh, M.H.; Bagdasarian, L.; Meyer, R.; et al. Inactivating mutations of RNF43 confer Wnt dependency in pancreatic ductal adenocarcinoma. Proc. Natl. Acad. Sci. USA 2013, 110, 12649-12654. [CrossRef] [PubMed]

223. Cheng, Y.; Phoon, Y.P.; Jin, X.; Chong, S.Y.; Ip, J.C.; Wong, B.W.; Lung, M.L. Wnt-C59 arrests stemness and suppresses growth of nasopharyngeal carcinoma in mice by inhibiting the Wnt pathway in the tumor microenvironment. Oncotarget 2015, 6, 14428-14439. [CrossRef] [PubMed]

224. Koo, B.K.; van Es, J.H.; van den Born, M.; Clevers, H. Porcupine inhibitor suppresses paracrine Wnt-driven growth of Rnf43;Znrf3-mutant neoplasia. Proc. Natl. Acad. Sci. USA 2015, 112, 7548-7550. [CrossRef] [PubMed]

225. Kahn, M. Can we safely target the WNT pathway? Nat. Rev. Drug Discov. 2014, 13, 513-532. [CrossRef] [PubMed]

226. Huang, S.M.; Mishina, Y.M.; Liu, S.; Cheung, A.; Stegmeier, F.; Michaud, G.A.; Charlat, O.; Wiellette, E.; Zhang, Y.; Wiessner, S.; et al. Tankyrase inhibition stabilizes axin and antagonizes Wnt signalling. Nature 2009, 461, 614-620. [CrossRef]

227. Stakheev, D.; Taborska, P.; Strizova, Z.; Podrazil, M.; Bartunkova, J.; Smrz, D. The WNT/beta-catenin signaling inhibitor XAV939 enhances the elimination of LNCaP and PC-3 prostate cancer cells by prostate cancer patient lymphocytes in vitro. Sci. Rep. 2019, 9, 4761. [CrossRef]

228. Bao, R.; Christova, T.; Song, S.; Angers, S.; Yan, X.; Attisano, L. Inhibition of tankyrases induces Axin stabilization and blocks Wnt signalling in breast cancer cells. PLOS ONE 2012, 7, e48670. [CrossRef]

229. Li, C.; Zheng, X.; Han, Y.; Lv, Y.; Lan, F.; Zhao, J. XAV939 inhibits the proliferation and migration of lung adenocarcinoma A549 cells through the WNT pathway. Oncol. Lett. 2018, 15, 8973-8982. [CrossRef]

230. Scarborough, H.A.; Helfrich, B.A.; Casas-Selves, M.; Schuller, A.G.; Grosskurth, S.E.; Kim, J.; Tan, A.C.; Chan, D.C.; Zhang, Z.; Zaberezhnyy, V.; et al. AZ1366: An Inhibitor of Tankyrase and the Canonical Wnt Pathway that Limits the Persistence of Non-Small Cell Lung Cancer Cells Following EGFR Inhibition. Clin. Cancer Res. 2017, 23, 1531-1541. [CrossRef]

231. Waaler, J.; Machon, O.; Tumova, L.; Dinh, H.; Korinek, V.; Wilson, S.R.; Paulsen, J.E.; Pedersen, N.M.; Eide, T.J.; Machonova, O.; et al. A novel tankyrase inhibitor decreases canonical Wnt signaling in colon carcinoma cells and reduces tumor growth in conditional APC mutant mice. Cancer Res. 2012, 72, 2822-2832. [CrossRef]

232. Arques, O.; Chicote, I.; Puig, I.; Tenbaum, S.P.; Argiles, G.; Dienstmann, R.; Fernandez, N.; Caratu, G.; Matito, J.; Silberschmidt, D.; et al. Tankyrase Inhibition Blocks Wnt/beta-Catenin Pathway and Reverts Resistance to PI3K and AKT Inhibitors in the Treatment of Colorectal Cancer. Clin. Cancer Res. 2016, 22, 644-656. [CrossRef] [PubMed]

233. Lau, T.; Chan, E.; Callow, M.; Waaler, J.; Boggs, J.; Blake, R.A.; Magnuson, S.; Sambrone, A.; Schutten, M.; Firestein, R.; et al. A novel tankyrase small-molecule inhibitor suppresses APC mutation-driven colorectal tumor growth. Cancer Res. 2013, 73, 3132-3144. [CrossRef] [PubMed]

234. Martins-Neves, S.R.; Paiva-Oliveira, D.I.; Fontes-Ribeiro, C.; Bovee, J.; Cleton-Jansen, A.M.; Gomes, C.M.F. IWR-1, a tankyrase inhibitor, attenuates Wnt/beta-catenin signaling in cancer stem-like cells and inhibits in vivo the growth of a subcutaneous human osteosarcoma xenograft. Cancer Lett. 2018, 414, 1-15. [CrossRef] [PubMed]

235. Waaler, J.; Machon, O.; von Kries, J.P.; Wilson, S.R.; Lundenes, E.; Wedlich, D.; Gradl, D.; Paulsen, J.E.; Machonova, O.; Dembinski, J.L.; et al. Novel synthetic antagonists of canonical Wnt signaling inhibit colorectal cancer cell growth. Cancer Res. 2011, 71, 197-205. [CrossRef]

236. Hua, Z.; Bregman, H.; Buchanan, J.L.; Chakka, N.; Guzman-Perez, A.; Gunaydin, H.; Huang, X.; Gu, Y.; Berry, V.; Liu, J.; et al. Development of novel dual binders as potent, selective, and orally bioavailable tankyrase inhibitors. J. Med. Chem. 2013, 56, 10003-10015. [CrossRef]

237. James, R.G.; Davidson, K.C.; Bosch, K.A.; Biechele, T.L.; Robin, N.C.; Taylor, R.J.; Major, M.B.; Camp, N.D.; Fowler, K.; Martins, T.J.; et al. WIKI4, a novel inhibitor of tankyrase and Wnt/ss-catenin signaling. PLoS ONE 2012, 7, e50457. [CrossRef]

238. Fang, F.; VanCleave, A.; Helmuth, R.; Torres, H.; Rickel, K.; Wollenzien, H.; Sun, H.; Zeng, E.; Zhao, J.; Tao, J. Targeting the Wnt/beta-catenin pathway in human osteosarcoma cells. Oncotarget 2018, 9, 36780-36792. [CrossRef]

239. Jang, G.B.; Hong, I.S.; Kim, R.J.; Lee, S.Y.; Park, S.J.; Lee, E.S.; Park, J.H.; Yun, C.H.; Chung, J.U.; Lee, K.J.; et al. Wnt/beta-Catenin Small-Molecule Inhibitor CWP232228 Preferentially Inhibits the Growth of Breast Cancer Stem-like Cells. Cancer Res. 2015, 75, 1691-1702. [CrossRef]

240. Cha, J.Y.; Jung, J.-E.; Lee, K.-H.; Briaud, I.; Tenzin, F.; Jung, H.K.; Pyon, Y.; Lee, D.; Chung, J.U.; Lee, J.H.; et al. Anti-tumor activity of novel small molecule Wnt signaling inhibitor, CWP232291, in multiple myeloma. Blood 2010, 116, 3038. [CrossRef] 
241. Fiskus, W.; Sharma, S.; Saha, S.; Shah, B.; Devaraj, S.G.; Sun, B.; Horrigan, S.; Leveque, C.; Zu, Y.; Iyer, S.; et al. Pre-clinical efficacy of combined therapy with novel beta-catenin antagonist BC2059 and histone deacetylase inhibitor against AML cells. Leukemia 2015, 29, 1267-1278. [CrossRef]

242. Fang, L.; Zhu, Q.; Neuenschwander, M.; Specker, E.; Wulf-Goldenberg, A.; Weis, W.I.; von Kries, J.P.; Birchmeier, W. A Small-Molecule Antagonist of the beta-Catenin/TCF4 Interaction Blocks the Self-Renewal of Cancer Stem Cells and Suppresses Tumorigenesis. Cancer Res. 2016, 76, 891-901. [CrossRef] [PubMed]

243. Hwang, S.Y.; Deng, X.; Byun, S.; Lee, C.; Lee, S.J.; Suh, H.; Zhang, J.; Kang, Q.; Zhang, T.; Westover, K.D.; et al. Direct Targeting of beta-Catenin by a Small Molecule Stimulates Proteasomal Degradation and Suppresses Oncogenic Wnt/beta-Catenin Signaling. Cell Rep. 2016, 16, 28-36. [CrossRef] [PubMed]

244. Takada, K.; Zhu, D.; Bird, G.H.; Sukhdeo, K.; Zhao, J.J.; Mani, M.; Lemieux, M.; Carrasco, D.E.; Ryan, J.; Horst, D.; et al. Targeted disruption of the BCL9/beta-catenin complex inhibits oncogenic Wnt signaling. Sci. Transl. Med. 2012, 4, 148ra117. [CrossRef] [PubMed]

245. Chen, Z.; Venkatesan, A.M.; Dehnhardt, C.M.; Dos Santos, O.; Delos Santos, E.; Ayral-Kaloustian, S.; Chen, L.; Geng, Y.; Arndt, K.T.; Lucas, J.; et al. 2,4-Diamino-quinazolines as inhibitors of beta-catenin/Tcf-4 pathway: Potential treatment for colorectal cancer. Bioorg. Med. Chem. Lett. 2009, 19, 4980-4983. [CrossRef] [PubMed]

246. Rahmani, F.; Amerizadeh, F.; Hassanian, S.M.; Hashemzehi, M.; Nasiri, S.N.; Fiuji, H.; Ferns, G.A.; Khazaei, M.; Avan, A. PNU-74654 enhances the antiproliferative effects of 5-FU in breast cancer and antagonizes thrombin-induced cell growth via the Wnt pathway. J. Cell. Physiol. 2019, 234, 14123-14132. [CrossRef]

247. Bilir, B.; Kucuk, O.; Moreno, C.S. Wnt signaling blockage inhibits cell proliferation and migration, and induces apoptosis in triple-negative breast cancer cells. J. Transl. Med. 2013, 11, 280. [CrossRef]

248. Lepourcelet, M.; Chen, Y.N.; France, D.S.; Wang, H.; Crews, P.; Petersen, F.; Bruseo, C.; Wood, A.W.; Shivdasani, R.A. Small-molecule antagonists of the oncogenic Tcf/beta-catenin protein complex. Cancer Cell 2004, 5, 91-102. [CrossRef]

249. Wei, W.; Chua, M.S.; Grepper, S.; So, S. Small molecule antagonists of Tcf4/beta-catenin complex inhibit the growth of HCC cells in vitro and in vivo. Int. J. Cancer 2010, 126, 2426-2436. [CrossRef]

250. Yao, H.; Ashihara, E.; Strovel, J.W.; Nakagawa, Y.; Kuroda, J.; Nagao, R.; Tanaka, R.; Yokota, A.; Takeuchi, M.; Hayashi, Y.; et al. AV-65, a novel Wnt/beta-catenin signal inhibitor, successfully suppresses progression of multiple myeloma in a mouse model. Blood Cancer J. 2011, 1, e43. [CrossRef]

251. Jarde, T.; Evans, R.J.; McQuillan, K.L.; Parry, L.; Feng, G.J.; Alvares, B.; Clarke, A.R.; Dale, T.C. In vivo and in vitro models for the therapeutic targeting of Wnt signaling using a Tet-ODeltaN89beta-catenin system. Oncogene 2013, 32, 883-893. [CrossRef]

252. Grandy, D.; Shan, J.; Zhang, X.; Rao, S.; Akunuru, S.; Li, H.; Zhang, Y.; Alpatov, I.; Zhang, X.A.; Lang, R.A.; et al. Discovery and characterization of a small molecule inhibitor of the PDZ domain of dishevelled. J. Biol. Chem. 2009, 284, 16256-16263. [CrossRef] [PubMed]

253. Fujii, N.; You, L.; Xu, Z.; Uematsu, K.; Shan, J.; He, B.; Mikami, I.; Edmondson, L.R.; Neale, G.; Zheng, J.; et al. An antagonist of dishevelled protein-protein interaction suppresses beta-catenin-dependent tumor cell growth. Cancer Res. 2007, 67, 573-579. [CrossRef] [PubMed]

254. DeAlmeida, V.I.; Miao, L.; Ernst, J.A.; Koeppen, H.; Polakis, P.; Rubinfeld, B. The soluble wnt receptor Frizzled8CRD-hFc inhibits the growth of teratocarcinomas in vivo. Cancer Res. 2007, 67, 5371-5379. [CrossRef] [PubMed]

255. Li, H.; Yu, C.; Jiang, J.; Huang, C.; Yao, X.; Xu, Q.; Yu, F.; Lou, L.; Fang, J. An anti-HER2 antibody conjugated with monomethyl auristatin $\mathrm{E}$ is highly effective in HER2-positive human gastric cancer. Cancer Biol. Ther. 2016, 17, 346-354. [CrossRef]

256. Chartier, C.; Raval, J.; Axelrod, F.; Bond, C.; Cain, J.; Dee-Hoskins, C.; Ma, S.; Fischer, M.M.; Shah, J.; Wei, J.; et al. Therapeutic Targeting of Tumor-Derived R-Spondin Attenuates beta-Catenin Signaling and Tumorigenesis in Multiple Cancer Types. Cancer Res. 2016, 76, 713-723. [CrossRef]

257. Liu, C.; Yu, X. ADP-ribosyltransferases and poly ADP-ribosylation. Curr. Protein Pept. Sci. 2015, 16, 491-501. [CrossRef]

258. Kulak, O.; Chen, H.; Holohan, B.; Wu, X.; He, H.; Borek, D.; Otwinowski, Z.; Yamaguchi, K.; Garofalo, L.A.; Ma, Z.; et al. Disruption of Wnt/beta-Catenin Signaling and Telomeric Shortening Are Inextricable Consequences of Tankyrase Inhibition in Human Cells. Mol. Cell. Biol. 2015, 35, 2425-2435. [CrossRef]

259. Wang, W.; Li, N.; Li, X.; Tran, M.K.; Han, X.; Chen, J. Tankyrase Inhibitors Target YAP by Stabilizing Angiomotin Family Proteins. Cell Rep. 2015, 13, 524-532. [CrossRef] 
260. Stratford, E.W.; Daffinrud, J.; Munthe, E.; Castro, R.; Waaler, J.; Krauss, S.; Myklebost, O. The tankyrase-specific inhibitor JW74 affects cell cycle progression and induces apoptosis and differentiation in osteosarcoma cell lines. Cancer Med. 2014, 3, 36-46. [CrossRef]

261. Quackenbush, K.S.; Bagby, S.; Tai, W.M.; Messersmith, W.A.; Schreiber, A.; Greene, J.; Kim, J.; Wang, G.; Purkey, A.; Pitts, T.M.; et al. The novel tankyrase inhibitor (AZ1366) enhances irinotecan activity in tumors that exhibit elevated tankyrase and irinotecan resistance. Oncotarget 2016, 7, 28273-28285. [CrossRef]

262. Busch, A.M.; Johnson, K.C.; Stan, R.V.; Sanglikar, A.; Ahmed, Y.; Dmitrovsky, E.; Freemantle, S.J. Evidence for tankyrases as antineoplastic targets in lung cancer. BMC Cancer 2013, 13, 211. [CrossRef] [PubMed]

263. Schoumacher, M.; Hurov, K.E.; Lehar, J.; Yan-Neale, Y.; Mishina, Y.; Sonkin, D.; Korn, J.M.; Flemming, D.; Jones, M.D.; Antonakos, B.; et al. Inhibiting Tankyrases sensitizes KRAS-mutant cancer cells to MEK inhibitors via FGFR2 feedback signaling. Cancer Res. 2014, 74, 3294-3305. [CrossRef] [PubMed]

264. Wang, H.; Lu, B.; Castillo, J.; Zhang, Y.; Yang, Z.; McAllister, G.; Lindeman, A.; Reece-Hoyes, J.; Tallarico, J.; Russ, C.; et al. Tankyrase Inhibitor Sensitizes Lung Cancer Cells to Endothelial Growth Factor Receptor (EGFR) Inhibition via Stabilizing Angiomotins and Inhibiting YAP Signaling. J. Biol. Chem. 2016, 291, 15256-15266. [CrossRef] [PubMed]

265. Riffell, J.L.; Lord, C.J.; Ashworth, A. Tankyrase-targeted therapeutics: Expanding opportunities in the PARP family. Nat. Rev. Drug Discov. 2012, 11, 923-936. [CrossRef] [PubMed]

266. Valenta, T.; Hausmann, G.; Basler, K. The many faces and functions of beta-catenin. EMBO J. 2012, 31, 2714-2736. [CrossRef]

267. Zhou, H.; Mak, P.Y.; Mu, H.; Mak, D.H.; Zeng, Z.; Cortes, J.; Liu, Q.; Andreeff, M.; Carter, B.Z. Combined inhibition of beta-catenin and Bcr-Abl synergistically targets tyrosine kinase inhibitor-resistant blast crisis chronic myeloid leukemia blasts and progenitors in vitro and in vivo. Leukemia 2017, 31, 2065-2074. [CrossRef]

268. Trautmann, M.; Sievers, E.; Aretz, S.; Kindler, D.; Michels, S.; Friedrichs, N.; Renner, M.; Kirfel, J.; Steiner, S.; Huss, S.; et al. SS18-SSX fusion protein-induced Wnt/beta-catenin signaling is a therapeutic target in synovial sarcoma. Oncogene 2014, 33, 5006-5016. [CrossRef]

269. Sukhdeo, K.; Mani, M.; Zhang, Y.; Dutta, J.; Yasui, H.; Rooney, M.D.; Carrasco, D.E.; Zheng, M.; He, H.; Tai, Y.T.; et al. Targeting the beta-catenin/TCF transcriptional complex in the treatment of multiple myeloma. Proc. Natl. Acad. Sci. USA 2007, 104, 7516-7521. [CrossRef]

270. Kim, J.Y.; Lee, H.Y.; Park, K.K.; Choi, Y.K.; Nam, J.S.; Hong, I.S. CWP232228 targets liver cancer stem cells through Wnt/beta-catenin signaling: A novel therapeutic approach for liver cancer treatment. Oncotarget 2016, 7, 20395-20409. [CrossRef]

271. Gonsalves, F.C.; Klein, K.; Carson, B.B.; Katz, S.; Ekas, L.A.; Evans, S.; Nagourney, R.; Cardozo, T.; Brown, A.M.; DasGupta, R. An RNAi-based chemical genetic screen identifies three small-molecule inhibitors of the Wnt/wingless signaling pathway. Proc. Natl. Acad. Sci. USA 2011, 108, 5954-5963. [CrossRef]

272. Trosset, J.Y.; Dalvit, C.; Knapp, S.; Fasolini, M.; Veronesi, M.; Mantegani, S.; Gianellini, L.M.; Catana, C.; Sundstrom, M.; Stouten, P.F.; et al. Inhibition of protein-protein interactions: The discovery of druglike beta-catenin inhibitors by combining virtual and biophysical screening. Proteins 2006, 64, 60-67. [CrossRef] [PubMed]

273. Tian, W.; Han, X.; Yan, M.; Xu, Y.; Duggineni, S.; Lin, N.; Luo, G.; Li, Y.M.; Han, X.; Huang, Z.; et al. Structure-based discovery of a novel inhibitor targeting the beta-catenin/Tcf4 interaction. Biochemistry 2012, 51, 724-731. [CrossRef] [PubMed]

274. Hahne, G.; Grossmann, T.N. Direct targeting of beta-catenin: Inhibition of protein-protein interactions for the inactivation of Wnt signaling. Bioorg. Med. Chem. 2013, 21, 4020-4026. [CrossRef] [PubMed]

275. Chae, W.J.; Ehrlich, A.K.; Chan, P.Y.; Teixeira, A.M.; Henegariu, O.; Hao, L.; Shin, J.H.; Park, J.H.; Tang, W.H.; Kim, S.T.; et al. The Wnt Antagonist Dickkopf-1 Promotes Pathological Type 2 Cell-Mediated Inflammation. Immunity 2016, 44, 246-258. [CrossRef]

276. Kimura, H.; Fumoto, K.; Shojima, K.; Nojima, S.; Osugi, Y.; Tomihara, H.; Eguchi, H.; Shintani, Y.; Endo, H.; Inoue, M.; et al. CKAP4 is a Dickkopf1 receptor and is involved in tumor progression. J. Clin. Investig. 2016, 126, 2689-2705. [CrossRef]

(C) 2019 by the authors. Licensee MDPI, Basel, Switzerland. This article is an open access article distributed under the terms and conditions of the Creative Commons Attribution (CC BY) license (http://creativecommons.org/licenses/by/4.0/). 